LOCKAEED MATTIN

ENVIRONMENTAL RESTORATION PROGRAM

\section{RECEIVED OCT 111996 \\ OSTI}

ES/ER/TM-201

\section{Terrestrial Habitat Mapping of the Oak Ridge Reservation: 1996 Summary}

This document has been approved by the K-25 Site Technical Information Office for release to the public. Date: $9 / 25 / 96$

ENERGY SYSTEMS 
This report has been reproduced directly from the best available copy.

Available to DOE and DOE contractors from the Office of Scientific and Technical Information, P.O. Box 62, Oak Ridge, TN 37831; prices available from 423-576-8401 (fax 423-576-2865).

Available to the public from the National Technical Information Service, U.S. Department of Commerce, 5285 Port Royal Rd., Springfield, VA 22161. 


\title{
Terrestrial Habitat Mapping of the Oak Ridge Reservation: 1996 Summary
}

\author{
R. A. Washington-Allen
}

T. L. Ashwood

Environmental Restoration Division

P. O. Box 2003

Oak Ridge, Tennessee 37831-7294

Date Issued-September 1996

Prepared by the

Environmental Sciences Division

Oak Ridge National Laboratory

Prepared for the

U.S. Department of Energy

Office of Environmental Management

under budget and reporting code EW 20

LOCKHEED MARTIN ENERGY SYSTEMS, INC.

managing the

Environmental Management Activities at the

Oak Ridge K-25 Site Paducah Gaseous Diffusion Plant

Oak Ridge Y-12 Plant Portsmouth Gaseous Diffusion Plant

Oak Ridge National Laboratory

under contract DE-AC05-84OR21400

for the

U.S. DEPARTMENT OF ENERGY 


\section{DISCLAIMER}

Portions of this document may be illegible in electronic image products. Images are produced from the best available original document. 


\section{PREFACE}

This report, Terrestrial Habitat Mapping of the Oak Ridge Reservation: 1996 Summary, ES/ER/TM-201, was prepared as a technical report documenting work performed under the Oak Ridge Reservation Wide Ecological Risk Assessment Program. This work was performed under Work Breakdown Structure 1.4.12.2.3.4 (Activity Data Sheet 8304, "Technical Integration"). This document provides the Environmental Restoration Program with information on changes in land use and land cover, including changes in spatial distribution, shape, amount of area lost and gained, presence and absence, degree of fragmentation or contiguity, and degree of interspersion between 1984 and 1994. This document also provides information on the potential spatial habitat distribution of two terrestrial species that may potentially be at risk from the effects of the operable units on the Oak Ridge Reservation. These results will be used in support of the ecological risk assessments for individual operable units and terrestrial species of concern.

\section{DISCLAIMER}

This report was prepared as an account of work sponsored by an agency of the United States Government. Neither the United States Government nor any agency thereof, nor any of their employees, makes any warranty, express or implied, or assumes any legal liability or responsibility for the accuracy, completeness, or usefulness of any information, apparatus, product, or process disclosed, or represents that its use would not infringe privately owned rights. Reference herein to any specific commercial product, process, or service by trade name, trademark, manufacturer, or otherwise does not necessarily constitute or imply its endorsement, recommendation, or favoring by the United States Government or any agency thereof. The views and opinions of authors expressed herein do not necessarily state or reflect those of the United States Government or any agency thereof. 


\section{CONTENTS}

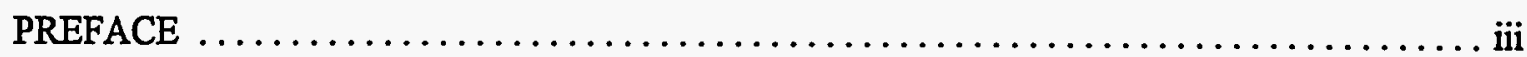

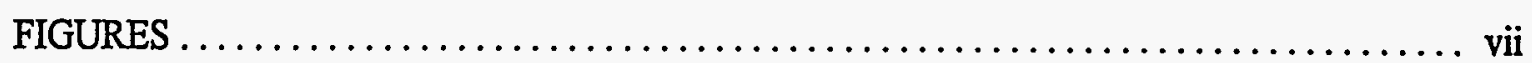

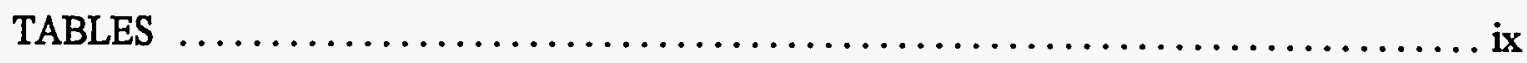

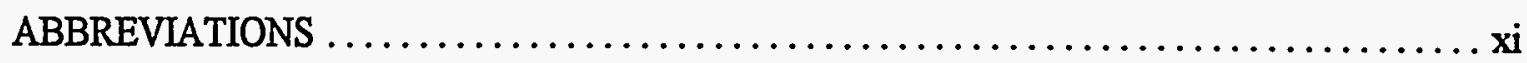

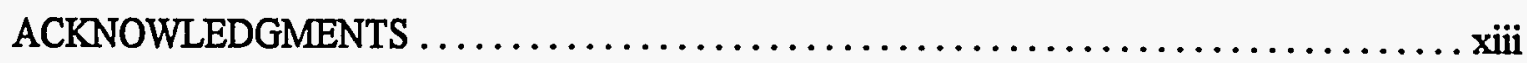

EXECUTIVE SUMMARY $\ldots \ldots \ldots \ldots \ldots \ldots \ldots \ldots \ldots \ldots \ldots \ldots \ldots \ldots \ldots \ldots \ldots \ldots$

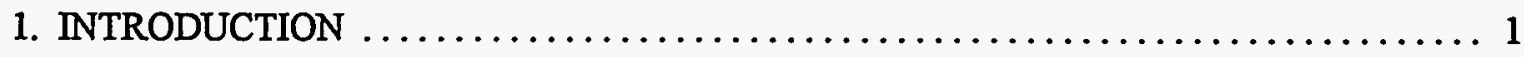

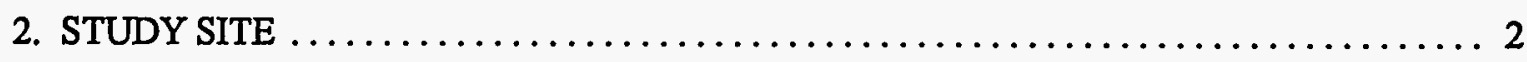

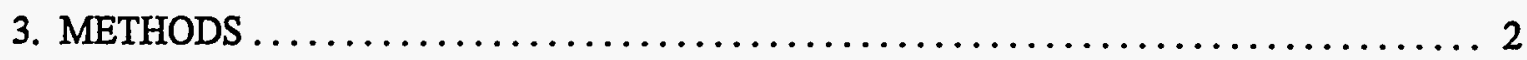

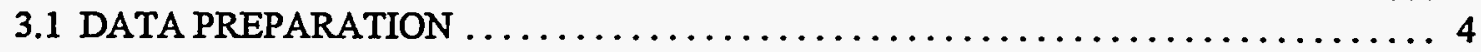

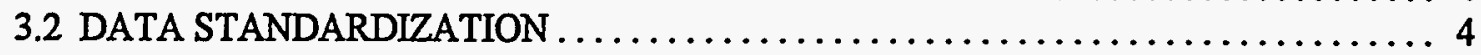

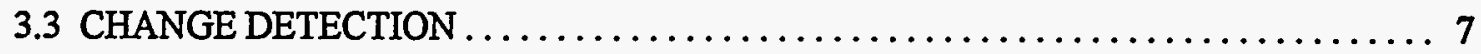

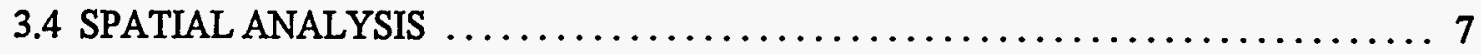

3.5 POTENTIAL SPECIES-HABITAT DISTRIBUTION MODELS $\ldots \ldots \ldots \ldots \ldots \ldots \ldots, 7$

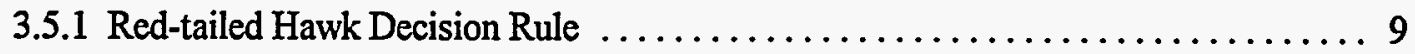

3.5.2 White-footed Mouse Decision Rule $\ldots \ldots \ldots \ldots \ldots \ldots \ldots \ldots \ldots \ldots \ldots \ldots$

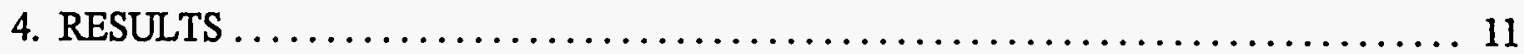

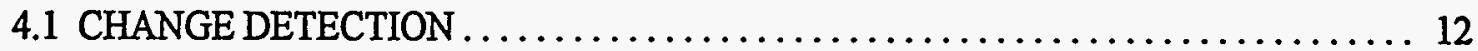

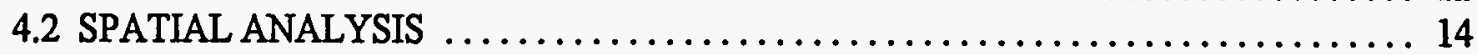

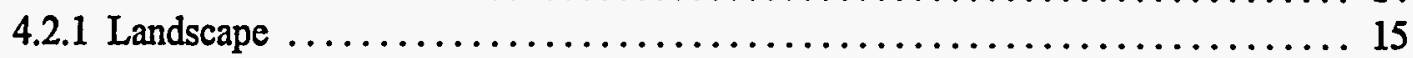

4.2 .2 Class $\ldots \ldots \ldots \ldots \ldots \ldots \ldots \ldots \ldots \ldots \ldots \ldots \ldots \ldots \ldots \ldots, 16$

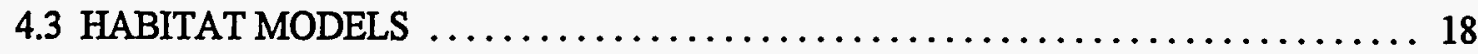

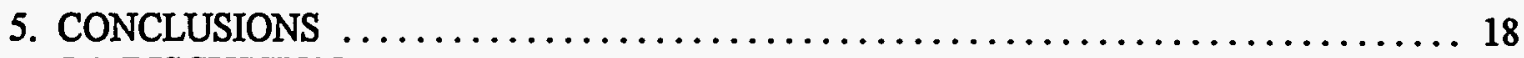

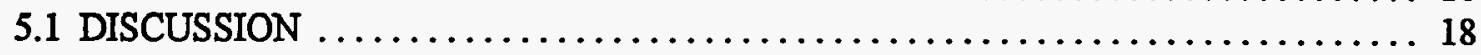

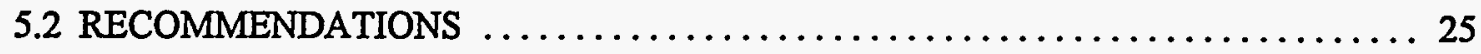

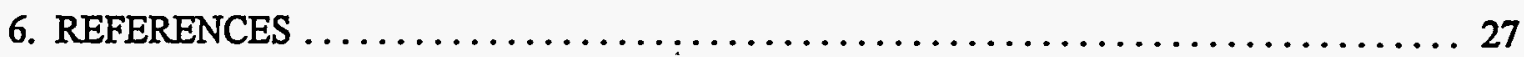




\section{FIGURES}

1. The Department of Energy's Oak Ridge Reservation $\ldots \ldots \ldots \ldots \ldots \ldots \ldots \ldots \ldots \ldots$

2. Comparison of September 5, 1984 and April 13, 1994 land-use/land-cover thematic maps of the Oak Ridge Reservation $\ldots \ldots \ldots \ldots \ldots \ldots \ldots \ldots \ldots \ldots \ldots \ldots \ldots \ldots$

3. Spatial distribution of areas of change in each land-use/land-cover class on the

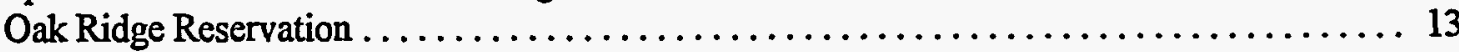

4. Potential nesting habitat distribution for red-tailed hawk on the Oak Ridge Reservation .... 19

5. Potential feeding habitat distribution for red-tailed hawk on the Oak Ridge Reservation .... 21

6. Potential habitat distribution for white-footed mouse on the Oak Ridge Reservation ...... 23 


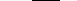




\section{TABLES}

1. Characteristics of 1984 and 1994 Landsat Thematic Mapper data acquired from EOSAT Corporation..$\ldots \ldots \ldots \ldots \ldots \ldots \ldots \ldots \ldots \ldots \ldots \ldots$

2. The Anderson-level land-use/land-cover classes used in the classification

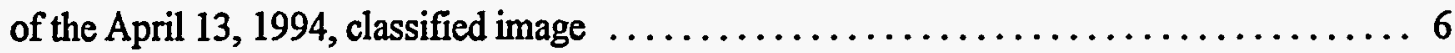

3. Comparison of the overall change in land use/land cover classes between 1984 and 1994

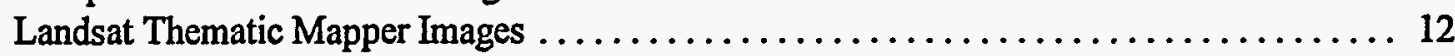

4. The area in hectares of each land use/land cover (LULC) in 1984 that has changed to another LULC in 1994 determined by MATRIX analysis (ERDAS 1994) . . . . . . . 14

5. The amount of area of a particular land cover/land use which remained unchanged

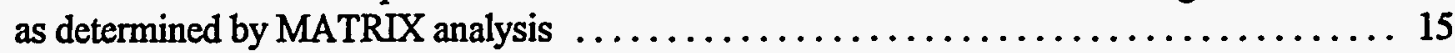

6. The percentage of a land use/land cover in 1984 which changed and did not change (where classes coincide) in 1994 as determined by SUMMARY analysis . . . . . . . . 15

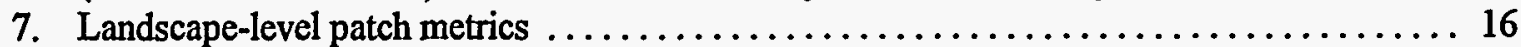

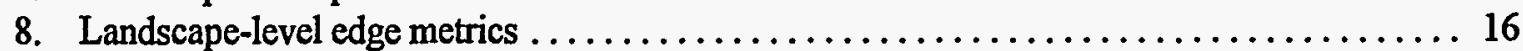

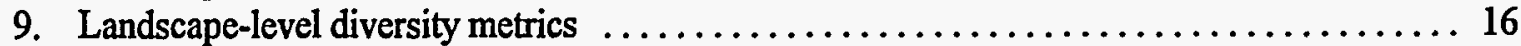

10. Class-level patch metrics (forest land and pasture land have become more fragmented) . .. 17

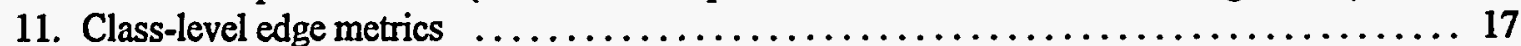

12. Class-level interspersion and juxtaposition metrics $\ldots \ldots \ldots \ldots \ldots \ldots \ldots \ldots \ldots \ldots$ 

DLFD Double Log Fractal Dimension

GIS geographic information system

IJI interspersion and juxtaposition index

LULC land-use/land-cover

ORR Oak Ridge Reservation

RMSE root mean square error

TM

Thematic Mapper 


\section{ACKNOWLEDGMENTS}

We would like to acknowledge Monica Turner of the University of Wisconsin; Holly Offerman of the University of Maryland; and Roxanna Hinzman, Brad Sample, and Robin Graham, all of the Environmental Sciences Division, for their help in developing the species habitat models and for the remote sensing data necessary for the multitemporal comparison. We would also like to thank our reviewers, Linda K. Mann and Tammy W. Beaty of the Environmental Sciences Division, for their time and helpful comments. 


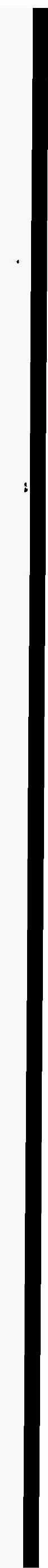




\section{EXECUTIVE SUMMARY}

The U.S. Department of Energy is in the process of remediating historical contamination on the Oak Ridge Reservation (ORR). Two key components of the environmental restoration program are ecological risk assessment and monitoring to assure that cleanup goals are met. In 1994, a strategy was developed for implementation of ecological risk assessment on the ORR, and a specific program was initiated to implement this strategy for the terrestrial biota of the entire ORR. This program consists of three primary tasks: (1) development of a habitat map and habitat models for key species of interest, (2) preparation of an ecological risk assessment for the entire ORR, and (3) collection of data needed to support the ecological risk assessment and to provide a baseline against which to assess the effects of remedial actions.

The first task was divided into two phases: (1) the classification and accuracy assessment of a 1994 Landsat 5 Thematic Mapper Image of the ORR into land-use/land-cover (LULC) categories and (2) development of species habitat relationship models within a geographic information system (GIS). This report presents the results of the second phase, the development of species habitat-relationship maps on the ORR, and also fulfills aspects of the third primary task. It was recommended in the first phase that the 1994 LULC map of the ORR be compared with a 1984 LULC map. The purpose of the LULC comparison was to assess the degree of change that has occurred over the past 10 years so as to (1) identify which land uses may affect species habitat loss, fragmentation, and/or alteration; and (2) determine how frequently the ORR LULC map should be updated.

One effect of land-use activities is the fragmentation and loss of habitat for various animal and plant species. Habitat models are a critical foundation for evaluation of the potential impact of historical (or ongoing) contamination on terrestrial biota of the ORR. The abundance and distribution of wildlife species and plant communities of concern are intrinsically linked to the abundance and distribution of habitat on which those species and communities rely. Thus, the impact of spatially discrete patches of contamination on those biota may be related to the degree of overlap between habitat and contamination.

The 1984 and 1994 LULC maps differed from each other by season acquired, level of precision used in the same hierarchical classification system, map projections, and spatial resolution. Procedures were developed to standardize the maps for comparison. Three procedures were then used to compare the two standardized maps: (1) a summary, which compared in tabular form the number of pixels in 1984 that changed to another category in 1994 ; (2) a matrix, which produces a map that visually indicates the location of change from one category to another; and (3) landscape ecology-based spatial statistics, which determined the degree of fragmentation, loss, and shape alteration at landscape and class levels.

In the 10-year period between surveys, $83 \%$ of the ORR landscape did not change; thus, $17 \%$ had changed. Of the percentage that had changed, the forest land-cover category had experienced both a $10 \%$ loss in area and increased fragmentation to smaller patches and, therefore, increased edge. These alterations may primarily be a result of conversion of $20.8 \%$ of forest to pasture land and is consistent with field estimates of conversion. The conversion to pasture land was probably caused by the harvest of pine beetle-infested evergreen forest. Conversely, some $43 \%$ of pasture land was converted to forest land, which is consistent with vegetation succession in the 10-year period. The patchiness of pasture had increased by $98 \%$ in this period. However, these measures of change must be considered overestimates 
because of the seasonal difference between images (fall 1984 and spring 1994), which tends to create patchiness because of lack of tree canopy in the early spring (1994), and the need to ground truth the sites of change with contemporaneous data (e.g., aerial photography or field survey data).

The 1994 LULC map was then used with digital layers of site biophysical characteristics (e.g., aspect, slope, elevation) within a GIS to model species habitat-relationships for two resident species on the ORR: the red-tailed hawk and the white-footed mouse. Nesting and feeding habitats were modeled for red-tailed hawk and general habitat for white-footed mouse through the use of binary and ordinal literature-based decision rules (i.e., arithmetic and conditional statements were used within GIS to generate the habitat models). For red-tailed hawk, potential nesting habitat comprised $\sim 2 \%$ of the ORR and potential feeding habitat comprised $21 \%$. Knowledge of feeding habitat distribution is important for the determination of the risk of oral exposure to contaminants. High-quality habitat for white-footed mouse comprised $20.6 \%$, medium quality comprised $60.1 \%$, and low quality comprised $12.7 \%$ of the ORR landscape. Quality of habitat was based on previous observations of Peromyscus density as determined by trapping success and percent dominance in small fauna measurements.

The rate of change for forest land on the ORR was $1.41 \mathrm{~km}^{2} / \mathrm{year}$, which, accounting for the overestimate, is comparable to the $0.80 \mathrm{~km}^{2} /$ year mean rate of change calculated from 1939 to 1964 for three counties in East Tennessee. However, this conversion rate suggests that shorter monitoring intervals are required to capture changes in LULC.

We make the following three recommendations:

1. Further GIS-based models of individual target species should be developed, and field sampling surveys to assess the accuracy of the change and distribution maps should be carried out.

2. Potential habitat models should be analyzed by spatial statistics to determine the degree of habitat alteration, loss, and fragmentation. This study indicates that fragmentation and alteration of the size of land-cover classes has occurred. The spatial pattern of habitats within landscapes may influence abundance, distribution, and dynamics of vertebrate populations. Fragmentation and the alteration of habitat size and geometry subdivides populations and may create a metapopulation structure that will affect the persistence of a species or functional group.

3. The ecological risk of radioactive and nonradioactive contaminants should be determined by relating their spatial distribution to the spatial distribution of terrestrial wildlife and their individual exposure tolerances. 


\section{INTRODUCTION}

During the last 50 years the U.S. Department of Energy's Oak Ridge Reservation (ORR) has been a relatively protected island of plant and animal habitats in a region of rapidly expanding urbanization (Mann et al. 1996). A preliminary biodiversity assessment of the ORR by the Nature Conservancy in 1995 noted 272 occurrences of significant plant and animal species and communities. Field surveys of threatened and endangered species (King, Awl, and Gabrielson 1994) show that the ORR contains 20 rare plant species, 4 of which are on the state list of endangered species. The rest are either on the state list of threatened species or listed as being of special concern. The ORR provides habitat for some 60 reptilian and amphibian species; more than 120 species of terrestrial birds; 32 species of waterfowl, wading birds, and shorebirds; and about 40 mammalian species (Parr and Evans 1992). The ORR provides habitat for the cerulean warbler (Dendroica cerulea) and the gray bat (Myotis grisescens), which is listed on the federal endangered species list. The ORR is both a refuge for rare species and a reservoir of recruitment for surrounding environments and wildlife management areas (Mann et al. 1996). The Natural Heritage Network ranking system identified by field survey 81 conservation areas of high or very high significance on the basis of clusters of rare species and plant communities. Cedar barrens, river bluffs, and wetlands have been identified as the habitat for most rare vascular plant species on the ORR (Mann et al. 1996).

A number of land-use activities on the ORR constitute a risk to these habitats. Land-use activities that present risks consist primarily of widely dispersed sites of contaminant storage and/or contamination and other land-use and/or natural disturbance activities that alter habitats. Natural disturbances on the ORR include tornadoes, wind throw, and pine-beetle outbreaks, which lead to land-use (management) practices such as logging, a forestry practice. Other land uses on the ORR include limited agriculture (pasture operation), urban and industrial expansion, road development, and alteration of waterways by beaver and human. Each type of land-use activity has different effects on natural resources. Thus, a whole range of land-use activities can occur, and their effects will vary. One effect of these land-use activities is fragmentation of the habitats of various animal and plant species. For example, alteration of waterways on the ORR by beaver and humans has caused changes in stream direction and floodplain distribution and this appears to continually change the distribution of aquatic contaminants (contained within stream-bed sediments) and terrestrial contaminants (contained within floodplains), thus changing the distribution and magnitude of risk exposure to both aquatic and terrestrial biota and the probable distribution of their habitats.

Ecologists have recognized that fragmentation, in particular, can have just as great an effect on habitat loss as can absolute change in area (Forman and Godron 1986; Askins, Ewert, and Norton 1989; Bierregaard et al. 1992). The impacts of cover changes as well as fragmentation can range from moderate to severe. Total elimination of some habitats can occur. Other habitats can merely be modified or fragmented. At least one third of the threatened or endangered species in the United States live in wetlands that are currently threatened by past and future land development (Murdock 1994). Thus, loss of habitats that may be altered by land management practices can affect a large number of species and change landscape biodiversity (Noss 1983).

The impacts of land-use change are a dynamic process in both time and space. Consequently, technologies are required that can aid in identifying and delineating different habitats, capturing changes in both space and time. Remote sensing from satellite platforms is a technology that has this capability through its ability to capture large areas [e.g., a $180 \mathrm{~km} \times 180 \mathrm{~km}$ area/image is covered by the Landsat 
Thematic Mapper (TM) satellite] and to sample repeatedly over long periods (e.g., Landsat satellites have sampled twice monthly for a 24-year period). Multitemporal satellite imagery coupled with geographic information system (GIS) technology can distinguish different habitats and dynamically map how they change in space and time and therefore provide insight into the effects of land-use change and natural disturbance on landscapes (Noss 1983; Stoms and Estes 1993). Therefore, if habitat use by individual species on the ORR can be inferred, then risk of exposure to contaminants or loss of biodiversity can be calculated. A similar protocol for mapping biodiversity on a regional scale, to determine risk from land-use, is conducted by the National Biological Service's GAP Analysis Project (Scott et al. 1993).

The objectives of this study were to

1. compare changes in land-use/land-cover class types between 1984 and 1994,

2. quantify and compare changes in landscape and land-use/land-cover class type's composition and pattern through the use of a spatial pattern analysis program, and

3. predict the potential habitat distribution for two species on the ORR that are representative of year-round residents and are potentially at risk from exposure to contaminants.

The results of this study are intended to answer the question as to how often we must sample in time to detect change on the ORR landscape with remote sensing-based monitoring.

\section{STUDY SITE}

The 14,266-ha ORR is situated in the southeastern United States deciduous forest between $84^{\circ} 26^{\prime}-84^{\circ} 11^{\prime} \mathrm{W}$ longitude and $35^{\circ} 52^{\prime}-36^{\circ} \mathrm{N}$ latitude (Fig. 1). Major plant communities and characteristic species include oak-hickory forests, native pine-hardwood forests, barrens, bottom land and riparian hardwood forests, loblolly pine plantations, northern hardwood forests, old fields, and grasslands (Mann et al. 1996). The ORR is located in the western part of the Valley and Ridge physiographic province at the narrowest and most convex part of the Appalachian foreland (the area towards which rocks were thrust or overfolded) fold-thrust belt (Hatcher et al. 1992).

\section{METHODS}

This chapter discusses the techniques used in to determine (1) the changes that have occurred for the ORR landscape between 1984 and 1994 and (2) the distribution of potential habitats for two resident vertebrate species-red-tailed hawk (Buteo jamaicensis) and white-footed mouse (Peromyscus leucopus). These two species were selected because they may be impacted by habitat alteration and loss as a result of land-use/land-cover change, particularly at contaminated sites on the ORR. The techniques used to develop potential species habitat models are a subset of GIS-based procedures, which are being developed to determine the ecological risk to target species from exposure to contaminants. This GIS model is an original conception for the examination of the effects of toxic substances on terrestrial biota and meets Cairns and Niederlehner (1996) requirements for the application of remote-sensing and GIS technology in the new field of landscape ecotoxicology. Consequently, only two potential species habitat 


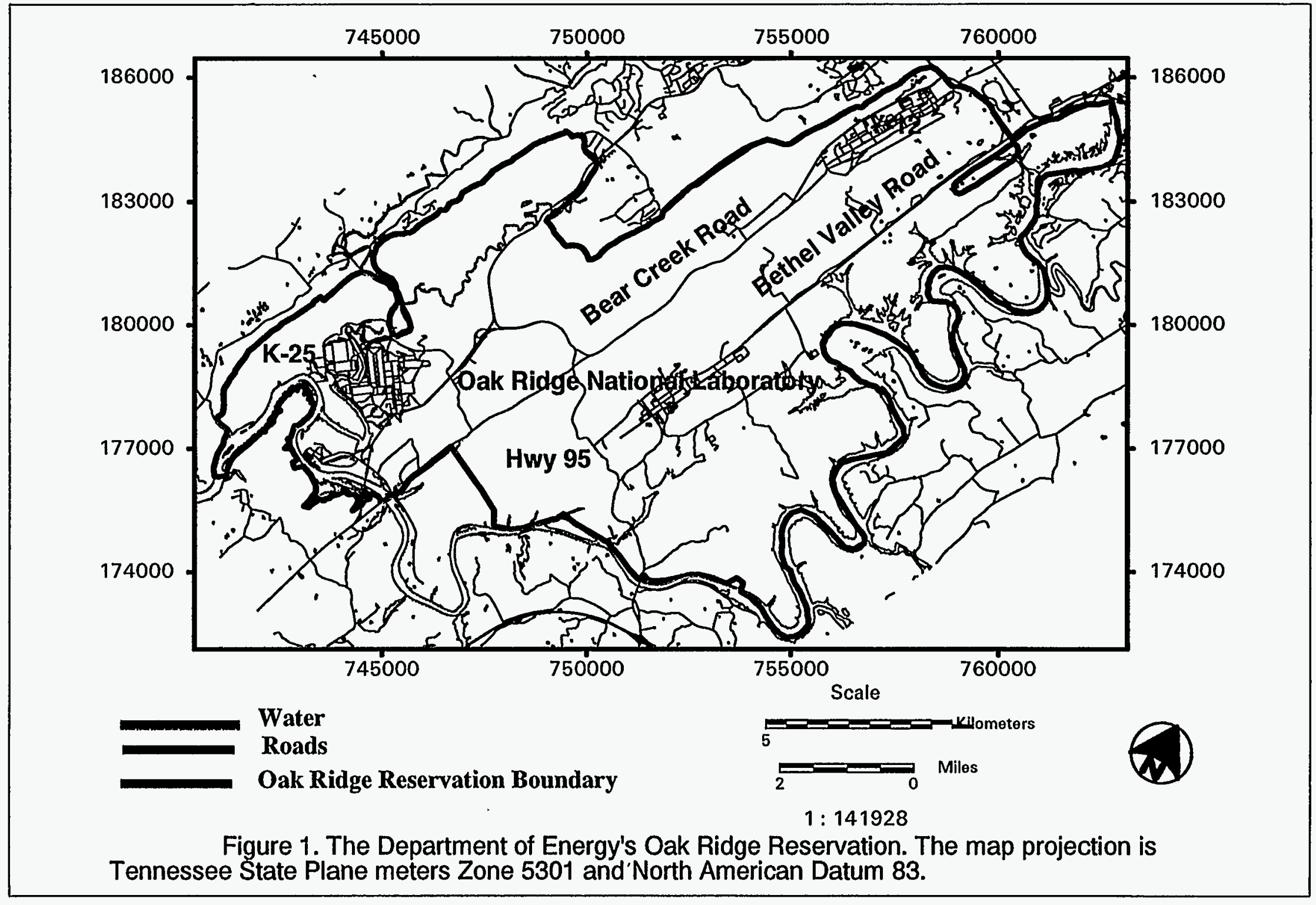


models are developed to aid development of a landscape-level, ecotoxicology/ecological risk assessment, GIS-based model.

\subsection{DATA PREPARATION}

Data preparation and processing took place at Oak Ridge National Laboratory's Environmental Sciences, Division Geographic Information Systems facility. A Sun Microsystems@ SPARC station 10 nunning Sun OS 4.1, ERDAS@ Imagine 8.2 ${ }^{\mathrm{TM}}$ and ARC/INFO ${ }^{\mathrm{TM}}$ GIS software ${ }^{1}$ were used to process the digital images.

\subsection{DATA STANDARDIZATION}

Table 1 shows the characteristics of both the 1984 and 1994 Landsat TM imagery, which were acquired from EOSAT Corporation. For the change detection analysis, each image was processed by using two different clustering algorithms and was taken from two different time periods [i.e., the 1984 image is from early fall (September 4), and the 1994 image is from spring (April 13)]. A single TM image actually consists of a seven-image sandwich of the same point on the earth, which is produced by seven separate sensors, each of which detects a unique part of the electromagnetic spectrum represented by reflected light from the earth's surface. These seven sensors detect visible light-red, green, and blue - and four types of infrared light. For example, if the amount of measured reflectance of a leaf, as detected by each TM sensor, is plotted against the visible and infrared in order of increasing wavelength (blue, green, red, infra-red, etc.) on a two-dimensional X-Y plot, then this represents the spectral characteristics or signature of the leaf.

Table 1. Characteristics of 1984 and 1994 Landsat Thematic Mapper data acquired from EOSAT Corporation

\begin{tabular}{|c|c|c|c|c|c|c|}
\hline Theme & Attributes & Dates & $\begin{array}{c}\text { Spatial } \\
\text { coverage }\end{array}$ & Resolution & Data type & Reference \\
\hline $\begin{array}{l}\text { Land } \\
\text { cover }\end{array}$ & $\begin{array}{l}\text { Anderson- } \\
\text { level I and II } \\
\text { land use and } \\
\text { land cover } \\
\text { categories }\end{array}$ & $9 / 5 / 84$ & $\begin{array}{l}89.4 \mathrm{~km} \times \\
126.6 \mathrm{~km} \text {; } \\
\text { entire site }\end{array}$ & $\begin{array}{l}30 \mathrm{~m} \\
\text { resampled } \\
\text { to } 25 \mathrm{~m}\end{array}$ & $\begin{array}{l}\text { Landsat Thematic } \\
\text { Mapper (TM) } 7 \times 8 \text {-bit } \\
\text { bands raster image, } \\
\text { quarter scene acquired } \\
\text { from EOSAT } \\
\text { Corporation raster }\end{array}$ & $\begin{array}{l}\text { Ashwood } \\
\text { et al. } 1994\end{array}$ \\
\hline $\begin{array}{l}\text { Land } \\
\text { cover }\end{array}$ & $\begin{array}{l}\text { Anderson- } \\
\text { level I and II } \\
\text { land use and } \\
\text { land cover } \\
\text { categories }\end{array}$ & $4 / 13 / 94$ & $\begin{array}{l}\sim 180 \mathrm{~km} \\
\times 180 \mathrm{~km} ; \\
\text { entire site }\end{array}$ & $\begin{array}{l}30 \mathrm{~m} \\
\text { resampled } \\
\text { to } 25 \mathrm{~m}\end{array}$ & $\begin{array}{l}\text { Landsat Thematic } \\
\text { Mapper (TM) } 7 \times 8 \text {-bit } \\
\text { bands raster image, full } \\
\text { scene acquired from } \\
\text { EOSAT Corporation }\end{array}$ & $\begin{array}{l}\text { Washington- } \\
\text { Allen et al. } \\
1995\end{array}$ \\
\hline
\end{tabular}

A TM image is divided into individual picture elements (pixels) that represent the area of the earth that the receptors receive light from. This pixel area is also called the detector's instant field of view and

\footnotetext{
${ }^{1}$ Reference herein to any specific commercial product, process, or service by trade name, trademark, manufacturer, or otherwise, does not necessarily constitute or imply its endorsement, recommendation, or favoring by the United States Government or any agency thereof.
} 
is $~ 30 \mathrm{~m} \times 30 \mathrm{~m}$ for a TM image. Thus, a typical TM image $(180 \mathrm{~km} \times 180 \mathrm{~km}$ in size $)$ contains $\sim 36$ million pixels. The spectral signature of unique objects on the face of the earth can be delineated by cluster analysis. Clustering algorithms are pattern recognition programs. Cluster analysis is used to identify homogenous areas (areas with the same spectral signature) within a satellite image. An analyst is then able to assign the clusters to uniform information categories (e.g., soils and forest), using previous knowledge of the site. The clustering algorithms used for the 1984 and 1994 images were a Minimum-Distance classifier called CLUSTR in ERDAS 7.5 (Ashwood et al. 1994 ) and a Maximum-Likelihood classifier respectively.

The Minimum-Distance classifier is an unsupervised classifier [i.e., it looks for "natural" spectrally homogenous regions (groups of pixels) within a satellite image and groups these into initial clusters]. The algorithm then calculates the minimum distance of the spectral signature of a pixel from each surrounding cluster and assigns it to the closest one. This is an iterative process and stops when a user-specified threshold of iterations and image diversity (number of categories) has been reached.

The Maximum-Likelihood classifier is a supervised classification methods [i.e., it uses analyst-defined training data or spectral signatures from known homogenous sites, such as a deciduous forest stand (Campbell 1987)]. It operates in principal the same way as does a Minimum-Distance classifier but is more sophisticated because in addition to the mean spectral signature it uses the standard deviation or variance of an individual pixel to compare it with different clusters (i.e., its variability) to decide its likelihood of belonging to a particular cluster (Campbell 1987). However, despite its sophistication, Campbell (1987) notes that there is little distinction among the final end products of image classification, especially where hybrid methods (a combination of unsupervised and supervised classification methods) and postprocessing corrections are used after an accuracy assessment to improve classification. This was the case in the preparation of both the 1984 and 1994 images where overall accuracy was assessed at $66 \%$ and $78 \%$, respectively. Accuracy assessment techniques are discussed in detail by Congalton (1991) and Washington-Allen et al. (1995).

With some modification, the same land-use/land-cover (LULC) classification system developed by Anderson et al. (1976) was used for both images. The Anderson-level system is hierarchical, which allows lower-level categories of high precision or finer resolution to be aggregated to higher levels of low precision or coarse resolution. Aggregation of lower-level categories to more general categories increases overall accuracy [though lowering precision (Campbell 1987)]. Thus, thematic maps generated from satellite imagery can be directly compared using this classification system. Table 2 shows the Anderson-level LULC categories used to classify the 1994 TM image (Washington-Allen et al. 1995), which were adapted from categories used to classify the 1984 image (Ashwood et al. 1994).

For the 1984 classification, there were two categories of urban-high and low density-and these were aggregated to Anderson-level I: urban. The 1984 agricultural land/bare ground and open grassland categories were aggregated to Anderson-level II: pasture land. There was some confusion in naming this category because on the ORR only one area is actually used as pasture land at Freels Bend. The rest is maintained lawn and gaps in pine forest that are a result of pine-beetle infestation and successional dynamics. An alternative category would be rangeland, but for purposes of comparison between images, pasture land was the most appropriate category. For the 1994 TM classified image the Anderson level-II subcategory of transitional areas was aggregated with the Anderson-level II category pasture land because this was the meaning conveyed by Ashwood et al. (1994). The cloud and cloud cover classes were also aggregated into one class. The barren land category was maintained as a unique class in the 1994 TM image as it depicts quarries and diggings not present in 1984 (Table 2). 
Table 2. The Anderson-level land-use/land-cover classes used in the classification of the April 13, 1994, classified image. The classes were adapted from Ashwood et al. (1994)

\begin{tabular}{|c|c|}
\hline $\begin{array}{l}\text { Land use/land } \\
\text { cover }\end{array}$ & Description \\
\hline Evergreen plantation & $\begin{array}{l}\text { Areas of pine trees that are row planted, are of uniform age, and are generally } \\
\text { younger than } 35 \text { years (in 1994) }\end{array}$ \\
\hline Water & Lakes, rivers, sewage ponds, ponds, and streams \\
\hline Urban land & $\begin{array}{l}\text { Mixture of administrative buildings, laboratories, heavy commercial and industrial } \\
\text { buildings, lawns, and clumped shade trees }\end{array}$ \\
\hline Evergreen forest land & $\begin{array}{l}\text { Areas dominated by mature pine forest type with trees generally older than } \\
35 \text { years (in 1994) and having an uneven canopy }\end{array}$ \\
\hline Barren land & $\begin{array}{l}\text { Cropped fields, plowed or bare ground areas, or areas where vegetation has been } \\
\text { removed, such as construction sites or quarries }\end{array}$ \\
\hline Deciduous forest land & Areas of hardwood forest types dominated by oaks and hickories \\
\hline Mixed forest land & Areas of a mixture of hardwoods and pine trees \\
\hline Pasture land & Fields with pasture grasses, grassland, row crops, and/or shrub land cover \\
\hline Transitional areas & $\begin{array}{l}\text { Secondary early successional sites, usually grassland to grassland shrub mix; } \\
\text { generally mowed along power line corridors }\end{array}$ \\
\hline
\end{tabular}

A second difference between the 1984 and 1994 images was seasonal. The 1984 image was taken in September and the 1994 in April. During April, deciduous trees are mostly leafless and can be easily distinguished from evergreen stands by the Landsat satellite's detectors. In contrast, during September evergreen and deciduous trees have full canopies and are not as easily distinguished, especially in mixed stands of uniform height and density. Although this does not pose a problem for nonforest categories, confusion between forest categories is possible and any change between forest classes could primarily be a result of seasonally driven phenological changes and not necessarily a result of vegetation succession or disturbance. Therefore, the forest classes-evergreen plantation, and evergreen, deciduous, and mixed forest land-were aggregated into a single category called forest land.

Further standardization concerned image-to-image registration and pixel size conversion. For image-to-image registration the two images were in different map projections (the $1984 \mathrm{TM}$ image was in Universal Transverse Mercator and the 1994 in Tennessee State Plane) and therefore could not be directly compared with each other by using overlay-based procedures. By using the 1994 image as the master, points on each image in the same area were chosen (called ground control points) and their coordinates mathematically compared with each other by using a curve fitting or regression-like procedure (Campbell 1987). A third-order polynomial was used to fit the 1984 Universal Transverse Mercator image to the 1994 Tennessee State Plane master image. The degree of misregistration between images, or the mean deviation of points from the polynomial, is called the root mean square error (RMSE). Jensen (1996) recommends a RMSE of $\leq \pm 2$ pixels for image fit and this was used in this study.

We addressed the difference in pixel-size between images, the 1984 image has $30 \mathrm{~m} \times 30 \mathrm{~m}$ pixels compared with the $25 \mathrm{~m} \times 25 \mathrm{~m}$ pixels of the 1994 image, by following a procedure called resampling. Resampling changes the size and orientation (map projection) of pixels. Jensen (1996) recommends a nearest-neighbor resampling procedure to maintain pixel values. ARC/INFO's GRID RESAMPLE 
procedure was used to change the 1984 image's pixels to a size of $25 \mathrm{~m} \times 25 \mathrm{~m}$. Figure 2 shows a comparison between the 1984 and 1994 images after standardization.

\subsection{CHANGE DETECTION}

Jensen (1996) reviews the methods used to perform change detections on unclassified and classified imagery. Jensen (1996) specifically describes the procedure for urban change detection of classified imagery. After the classified images were standardized, comparisons were made between images through the use of ERDAS Imagine's SUMMARY and MATRIX modules. A summary algorithm produces cross-tabulation statistics that compare class values between thematic images, including the number of pixels and amount of area and/or percentage of landscape in common (ERDAS 1994). One input image is called the zone layer and is the analysis layer. The other input image is called the class layer. The number of pixels or amount of area of each class within a zone are compared. For example, if we overlay United States' county boundaries against United States' state boundaries, each state is a zone and each county within the state is a class. In this study, the 1984 image was the zone layer and the 1994 image was the class layer. A matrix algorithm visually indicates how the class values between images overlap spatially in a map. This provides visual indication of where actual changes are located.

After a matrix layer was produced, an additional procedure to account for misregistration or misoverlap error was carried out. An RMSE of $\leq \pm 2$ pixels suggests an error area of $5 \times 5$ pixels, or $\sim 1.6 \mathrm{ha}\left[\left(625 \mathrm{~m}^{2} \times 25\right.\right.$ pixels $\left.) / 10000 \mathrm{~m}^{2}\right]$. A clumping algorithm was run to identify the location and size (area) of contiguous pixels or clumps. Finally, a sieving algorithm is run to remove clumps that are $\leq 25$ pixels. This procedure increases our confidence in the amount of change observed by removing spurious pixels from further analysis.

\subsection{SPATIAL ANALYSIS}

Landscape pattern metrics were developed to quantitatively describe landscape composition and pattern (O'Neill et al. 1988; Turner and Gardner 1991). Turner (1989), Tumer and Gardner (1991), and McGarigal and Marks (1995) provide reviews of landscape ecology's development and a guide to 50 landscape metrics. A requirement of landscape metrics set by $0^{\prime} \mathrm{Neill}$ et al. (1988) was that they be independent of each other. Ritter et al. (1995) demonstrated the functional equivalence of 50 landscape metrics and reduced them to 6 [i.e., contagion, standardized patch shape, patch-perimeter-area scaling, average perimeter-area ratio, number of attribute classes (diversity), and large-patch density-area scaling]. The metrics are usually related to changes in specific habitat attributes required by a particular species (e.g., McGarigal and McComb 1995). However, in this study landscape metrics are used to compare change at the landscape and class-levels because it allows an estimate of change between thematic maps unbiased by overlay-based procedures and thus registration error. The weakness of this method compared to overlay procedures is that the metrics do not show where change has occurred (McGarigal and Marks 1995). The spatial analysis software FRAGSTATS was used to analyze spatio-temporal changes between the 1984 and 1994 images (McGarigal and Marks 1995).

\subsection{POTENTIAL SPECIES-HABITAT DISTRIBUTION MODELS}

Two basic methods are available for the inventory of a species' distribution in nature: (1) overlay of range maps or tabular distribution data or (2) modeling of species' distributions from environmental 


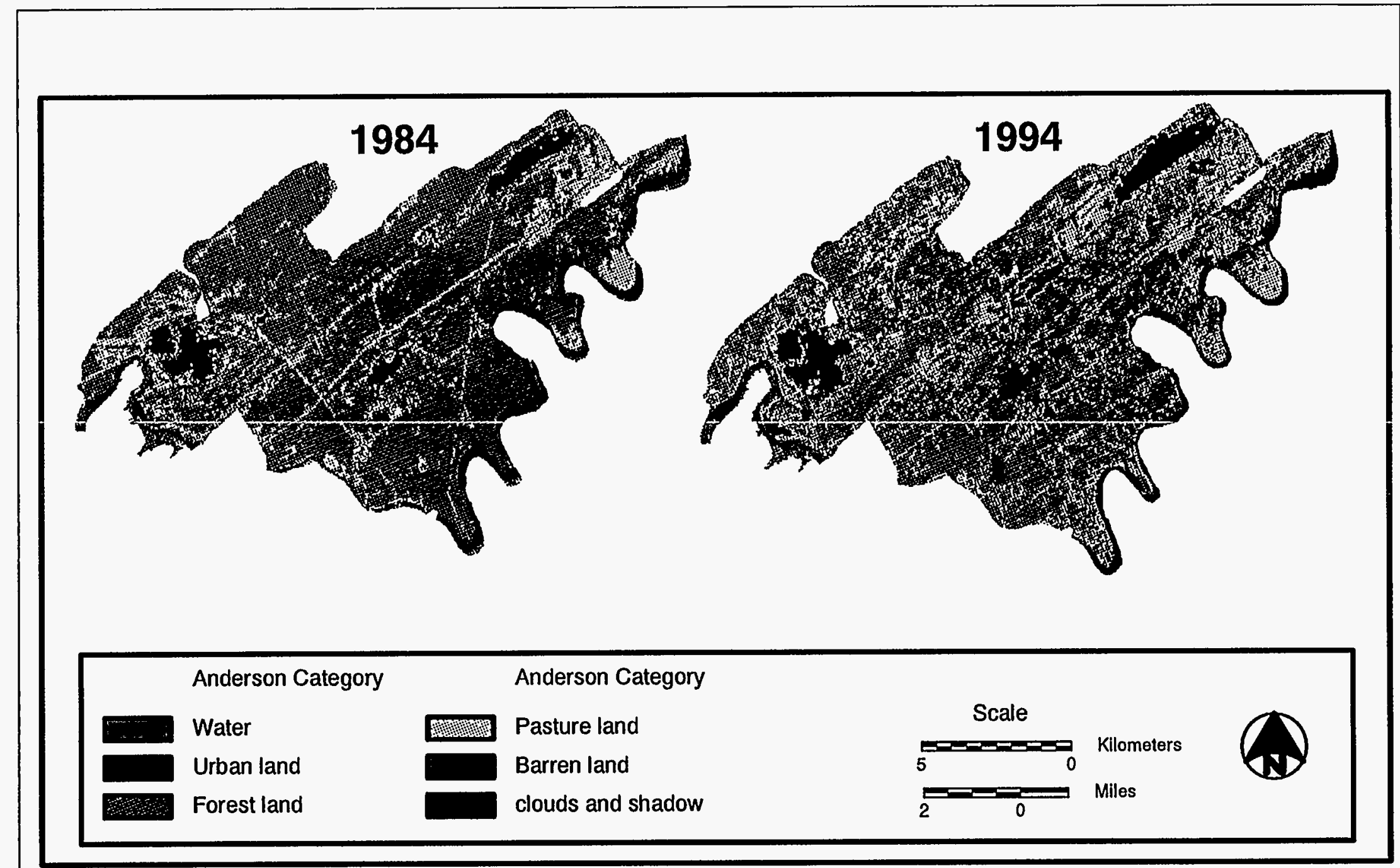

Figure 2. Comparison of September 5, 1984 and April 13, 1994 land-use/land-cover thematic maps of the Oak Ridge Reservation. The map projection is Tennessee State Plane meters Zone 5301 and North American Datum 83. Note that most pasture land is transitional area (pine beetle infested forest). 
variables (Stoms and Estes 1993). Range map or tabular distribution data are usually determined by inductive methods (i.e., observational or literature review studies of actual species distribution). Species-habitat relationship modeling is a deductive method that involves experimentation and hypothesis testing of a basic tenet of biogeographical theory that each species has an "ecological niche," a set of requirements for resources and physical conditions where it can live and reproduce (Stoms and Estes 1993). Range maps are limited because they are static; they assess a species distribution at one step in time and may miss changes in species distribution in response to environmental fluctuations. More dynamic representations are possible through real-time telemetry (i.e., global positioning systems and radio collar combinations) but are expensive and time-consuming. Species-habitat relationship models are limited in that the predicted suitable habitat does not necessarily correspond to the species' actual habitat and is usually an overestimate (Stoms and Estes 1993).

Because it is amenable to dynamic modeling (i.e., temporal updates) and less labor-intensive, less expensive, and less time-consuming than range maps, species-habitat relationship modeling is the approach taken in this report for modeling the habitat distribution of two species-red-tailed hawk (Buteo jamaicensis) and white-footed mouse (Peromyscus leucopus). Species-habitat relationship modeling from a GIS perspective involves the identification of biophysical parameters or ecological attributes that biologists believe are important for each species of interest. These ecological attributes can be viewed as constraining factors that influence the distribution of a species in nature. Each ecological attribute is a layer in a GIS. The models are usually presented as suitability ratings by biologists using binary (suitable and unsuitable), ordinal (high, medium, low), or ratio (an index score) values (Stom and Estes 1993). We use a combination of binary and ordinal approaches to develop GIS ecological decision rules; this is also known as "rules of combination" method (Hopkins 1977; Westman 1985; Burrough 1986).

\subsubsection{Red-tailed Hawk Decision Rule}

Red-tailed hawk (Buteo jamaicensis) is a large ( $46-63 \mathrm{~cm}$, wing span $1.2 \mathrm{~m}$ ) hawk with a whitish breast and a rust-colored tail. It has a range from Alaska and Nova Scotia south to Panama. It winters north to British Columbia and the Maritime Provinces and is the most common and widespread of the American members of the genus Buteo (Sutton and Sutton 1985). It is a resident wide-ranging avian species on the ORR (Sample, Baron, and Jackson 1995). Its wide range is the characteristic believed to place it at risk from exposure to widely dispersed contaminants on the ORR (Sample, Baron, and Jackson 1995). Red-tailed hawk populations have also been observed to respond to habitat alterations in forest horizontal and vertical structural diversity, stand diversity, size class distribution, and vegetation species composition (Nelson and Titus 1988). Two different types of potential habitat for red-tailed hawk - nesting and feeding habitat-were modeled within a GIS, although it is more likely that feeding habitat is the vector site for exposure to contaminants. The rules of combination for red-tailed hawk were derived from a quantitative statistical study of nesting-site selection in a managed loblolly pine (Pinus taeda) plantation in central Georgia by Morman and Chapman (1996). Feeding habitat decision rules derived from this study divided feeding habitat into three ordinal categories-high, medium, and low. The high-quality feeding habitat was pasture land or transitional areas within $100 \mathrm{~m}$ of a forest edge. Moderate-quality feeding habitat was any other pasture land or transitional areas. Low quality was all other types of land cover (Morman and Chapman 1996).

The GIS rules of combination for nesting habitat of red-tailed hawk were derived from two quantitative studies on nest-site selection by Morman and Chapman (1996) and Titus and Mosher (1981). The Titus and Mosher (1981) study took place in western Maryland in the Central Appalachians. Both studies took place in the oak-pine-hickory plant community association described by Braun (1950) and Greller (1988). The ORR is within the oak-chestmut association (Braun 1950; Greller 1988), which 
is similar in vertical and horizontal structural diversity of hardwood and pine species to the oak-pine-hickory association. The ORR also contains evergreen (pine) plantations (Table 2) similar in structure to the pine stands in the Morman and Chapman (1996) study. Both studies used standard inferential (Morman and Chapman 1996) and multivariate (discriminant analysis, Titus and Mosher 1981) statistics to determine which habitat attributes determined the distribution of nest sites; specific discriminant variables were (1) different types of land cover including agricultural, pine, and upland and bottom land hardwood habitat types; (2) edge density and distance from edge; (3) forest stand structure (e.g., stand height, density, diameter at breast height); (4) distance from water (Titus and Mosher 1981); and (5) age of stand.

The following nesting habitat decision rules were based on their findings:

High quality: Land cover $=$ deciduous forest, mixed forest, evergreen forest, evergreen plantation; land cover $\neq$ floodplain; slope $=20-60 \%$; aspect $=$ east-facing; distance to water $=100-500 \mathrm{~m}$.

Medium quality: Same land cover types as for high quality; slope $=5-20 \%$ or $60-80 \%$; any aspect; distance to water $=30-100 \mathrm{~m}$.

Low quality: Any nonforested land cover type; any area within floodplains; any slope $<5 \%$; distance to water $<30 \mathrm{~m}$ or $>500 \mathrm{~m}$ (Morman and Chapman 1996).

GIS data layers are determined by the decision rules for individual species. The data layers which were used are the original 1994 thematic LULC map (Washington-Allen et al. 1995, Table 1), attributes of which are in Table 2; slope and aspect, which were derived from a $30 \mathrm{~m} \times 30 \mathrm{~m}$ pixel-resolution digital elevation model of the ORR (Smyre 1994); distance from water; and 50-year floodplain data (Tennessee Valley Authority 1991). Floodplain delineations were based on topographic data compiled from natural color aerial photography taken in April, 1993, and is an incomplete coverage because work is still in progress delineating the East Fork Poplar Creek Watershed Region (Dan Levine, July 22, 1996, personal communication).

Distance from water was derived by using ARC/INFO's BUFFER and POLYGRID modules and ERDAS Imagine 8.2 on a hydrology vector coverage of the ORR. The hydrology coverage was digitized from the S-16A administrative map of the ORR (Tennessee Valley Authority 1988). The coverage was buffered according to the nesting habitat decision rules (e.g., 100-500 m) by creating two buffered polygon coverages of $100 \mathrm{~m}$ and $500 \mathrm{~m}$. The $500 \mathrm{~m}$ coverage was converted to a raster through the use of POLYGRID and then to an ERDAS Imagine raster image file. The ERDAS Imagine's viewer raster modules, Raster and Attribute Editors, were used to recode the $500 \mathrm{~m}$ buffer coverage to three classesnull, $>500 \mathrm{~m}$, and $<500 \mathrm{~m}$. The $100 \mathrm{~m}$ buffer coverage was overlain on the $500 \mathrm{~m}$ raster image in ERDAS Imagine. The $100 \mathrm{~m}$ buffer polygon coverage was converted to an area of interest and the viewer raster module, Raster Editor (RECODE module), was used to recode the area of the $500 \mathrm{~m}$ buffer image inside the area of interest. The image was then attributed to four classes-null, $>500 \mathrm{~m}, 100-500 \mathrm{~m}$, and $<100 \mathrm{~m}$. A similar procedure was carried out for the $30 \mathrm{~m}$ buffer. Similar recode procedures were carried out for the slope and aspect images by using ERDAS Imagine's Spatial Modeler Tool. The Spatial modeler was used to recode all input layers to 3 attribute files-null $=0$, unsuitable $=1$, and suitable $=2$-and mathematically combined to produce the three different output layers.

ERDAS Imagine's SEARCH module, a GIS proximity analysis program, was used to delineate the distance $100 \mathrm{~m}$ from forest edge for the high-quality feeding habitat model. The resulting raster layer was intersected (added) with the 1994 LULC thematic map of the ORR, which had been recoded to only pasture land and transitional areas. The result of this procedure was a layer representing the intersection 
of the $0-100 \mathrm{~m}$ area from forest edge with pasture land and transitional areas. The same data layers are then recoded to fit the criteria for moderate and low feeding habitat.

\subsubsection{White-footed Mouse Decision Rule}

The white-footed mouse has large ears (13-14 mm long) and is $15.6-20.5 \mathrm{~cm}$ in length. Its color is grayish-to-dull orange-brown above and white below. Its tail is similarly bicolored and nearly one-half its total length. Its range is the eastern United States, and it is usually active year-round, but a few may hibernate (Sutton and Sutton 1985). The model for white-footed mouse is based entirely on information from the ORR. The principle source of the information is a small mammal research study conducted by Greenberg, Pelton, and Parr (1988) as part of a larger study on gray fox (Urocyon cinereoargenteus) as well as expert knowledge derived from Oak Ridge National Laboratory's Environmental Sciences Division's wildlife biologists. Because white-footed mice are a primary component of the diet of gray fox, prediction of their habitat distribution provides a surrogate estimate of the feeding habitat of gray fox. Development of this model therefore provides an example of using prey-predator relationships or ecological interactions between biota as a means to predict habitat distribution.

Greenberg, Pelton, and Parr's (1988) study divided habitat into three ordinal categories-high, medium, and low quality - based on the relative density of white-footed mouse in a particular habitat type. Density categories were determined by trapping success and percent dominance of white-footed mice within the small mammal fauna (Greenberg, Pelton, and Parr 1988).

The following habitat decision rules were based on Greenberg, Pelton, and Parr's (1988) findings:

High-quality habitat: Evergreen forest; deciduous and mixed forest within floodplains; old-field grasslands within $100 \mathrm{~m}$ of a forest/grassland edge including power line right of ways.

Medium-quality habitat: Deciduous and mixed forest that are not within floodplains; old-field grasslands greater than a $100 \mathrm{~m}$ from a forest/grassland edge; evergreen plantation.

Low-quality habitat: Pasture land and urban land, both of which contain maintained grasslands (e.g., around buildings and in burial grounds); very early successional grasslands on sites where there has been human disturbance (e.g., Clinch River Breeder Reactor site and burial ground in Bear Creek Valley).

Procedures for this model were similar to and used data layers from the red-tailed hawk model. For purposes of this model, transitional areas are considered old-field grassland (Table 2) and pasture land are maintained grassland. Data layers developed for red-tailed hawk were used where appropriate in developing the models for white-footed mouse. The GIS models for both species called for a data layer that provided information on age of grasslands and forest types, but this data was unavailable in digital format.

\section{RESULTS}

We report the results of three analyses: (1) change detection, (2) spatial analysis between 1984 and 1994 Landsat TM images, and (3) spatial habitat modeling of habitat for two vertebrate species. 


\subsection{CHANGE DETECTION}

Overall, forest cover has decreased by $10 \%$, urban land has increased by $3 \%$, and pasture land has increased by $9 \%$ between 1984 and 1994 (Table 3). The changes to and from water, an overall decrease of $1 \%$, probably reflects either seasonal flow and, thus, floodplain changes, and some misregistration error. The barren lands were a class that was present during 1984, but Ashwood et al. (1994) had apparently designated this category as bare-soil and combined it with agricultural land (Table 3 ). However, discrimination of this class was particularly good in 1994, probably because of low canopy cover, and the category was kept separate. The barren lands tend to be mostly quarries (Table 2).

Table 3. Comparison of the overall change in land use/land cover classes between 1984 and 1994 Landsat Thematic Mapper Images

\begin{tabular}{lcc}
\hline \multicolumn{1}{c}{ Class } & $\begin{array}{c}\text { Percentage of landscape } \\
\text { in 1984 }\end{array}$ & $\begin{array}{c}\text { Percentage of landscape } \\
\text { in 1994 }\end{array}$ \\
\hline Water & 7 & 6 \\
Urban & 8 & 10 \\
Forest land & 70 & 60 \\
Pasture land & 14 & 23 \\
Barren land & 0 & 0.3 \\
\hline
\end{tabular}

Table 4 accounts for LULC conversions and shows addition and subtractions to a particular class, (e.g., 148.3 ha of forest has changed to water and 120.4 ha of water has changed to forest). Both Table 4 and Fig. 3 are the results of Imagine's MATRIX analysis, a cross-tabulation overlay of the amount of each LULC that changed from one class to another between 1984 and 1994. This procedure is sensitive to misregistration. Consistent patterns in a matrix map can be indicative of areas of misregistration. The most consistent linear features in the matrix image (Fig. 3) is the water category along the Clinch River and. the pasture land to forest land change category. The pasture land to forest land change category is the linear feature going from east to west across the middle of the image. It can also be slightly seen running north to south in the western portion of the ORR (Fig. 3). These features were initially thought to be indicative of poor registration, but a test and an observation were performed that argue against this view.

The 1984 and 1994 thematic maps were overlain together in ERDAS Imagine through the use of the viewer modules Blend/Fade, Flicker, and Swipe to test the efficacy of the registration. Blend/Fade does just that, causing the overlay top image 1984 to slowly fade in and fade out over the bottom 1994 image. Flicker switches between images at a set rate, and swipe allows you to window shade the top image in vertical and horizontal directions. All three methods are visualization tools for qualitative comparison of overlay fit.. They all indicate no significant visual errors in registration. In Fig. 2, the 1984 thematic map, category pasture land more clearly demarcates this feature. It is a power line corridor that runs across the reservation. It is not as clearly demarcated in 1994 and in fact is dominated by the forest land category. This is probably a result of vegetation succession of grassland/shrub land to forest land. Therefore, one would expect a pasture to forest land conversion. 


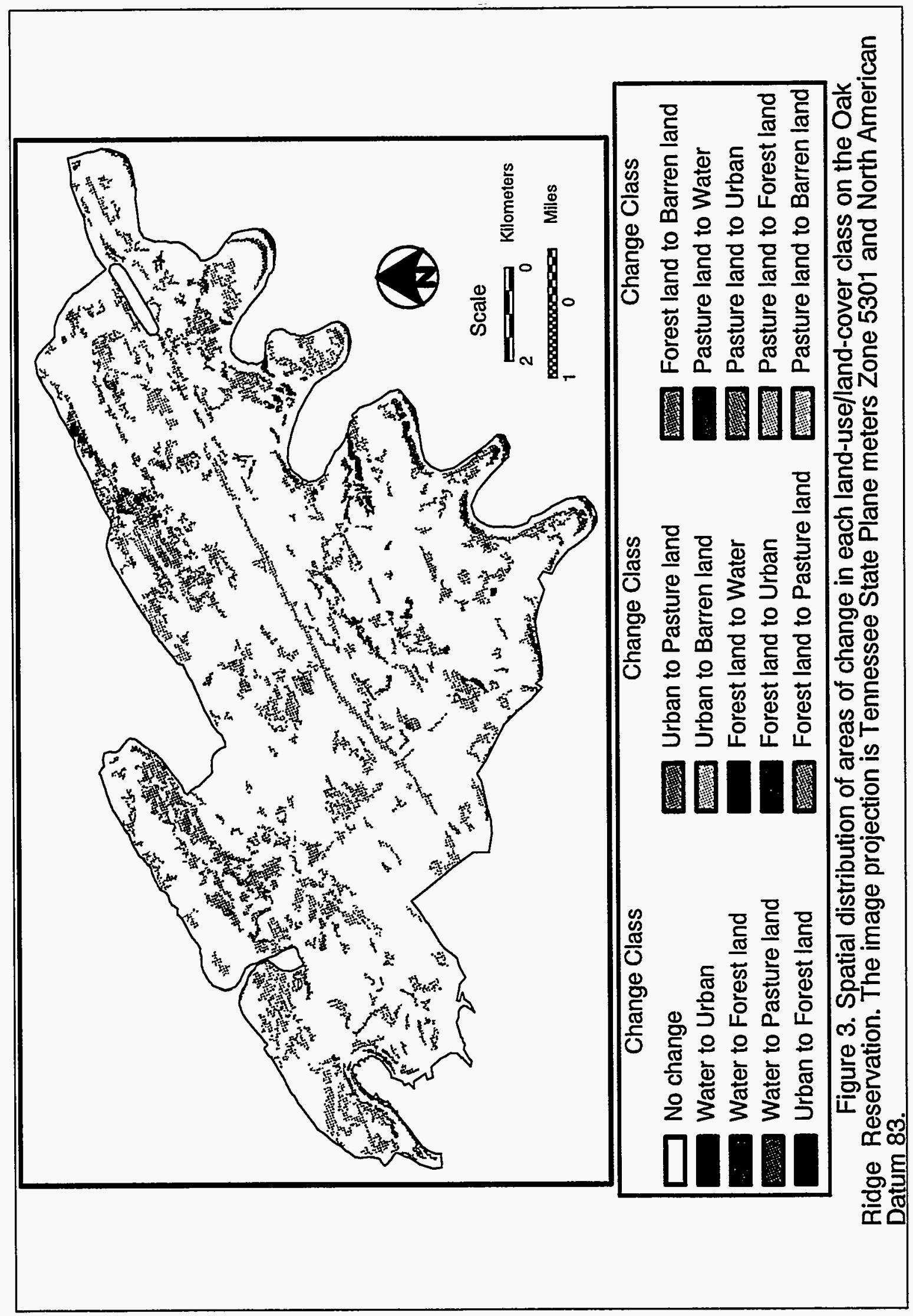


Table 4. The area in hectares of each land use/land cover (LULC) in 1984 that has changed to another LULC in 1994 determined by MATRIX analysis (ERDAS 1994)

\begin{tabular}{lc}
\multicolumn{1}{c}{ Class } & $\begin{array}{c}\text { Area changed from 1984 to 1994 } \\
\text { (in ha) }\end{array}$ \\
\hline Water to urban & 6.5 \\
Water to forest land & 120.4 \\
Water to pasture land & 76.8 \\
Urban to forest land & 20.1 \\
Urban to pasture land & 49.7 \\
Urban to barren land & 3.1 \\
Forest land to water & 148.3 \\
Forest land to urban & 139.6 \\
Forest land to pasture land & 1236.81 \\
Forest land to barren land & 19.3 \\
Pasture land to water & 12.7 \\
Pasture land to urban & 109.9 \\
Pasture land to forest land & 478.7 \\
Pasture land to barren land & 10.7 \\
Total & 2432.7 \\
\hline
\end{tabular}

The largest conversion of forest land, 1237 ha $(20.8 \%)$, has been to pasture land. Table 5 accounts for the amount of area within each LULC that has not changed. Table 6 is a summary of the results of the ERDAS Imagine's Module SUMMARY. It is a slight overestimate of the percentage change because misregistration error has not been corrected as it was for the MATRIX analysis. For forest land, 73.6\% of it has remained unchanged, and $3.4 \%$ became urban land (Table 6). Urban land apparently experienced a large conversion to forest land and pasture land, $12.7 \%$ and $19.1 \%$, respectively. These all appear to be edge pixels between urban and forest land and urban and pasture land transition zones (Fig. 3) and thus, mixed pixels (pixels where the spectral signatures have been misclassified, Jensen 1996). The largest conversion of pasture land was $43.2 \%$ to forest land. Figure 3 shows the individual patches where these conversions have taken place.

\subsection{SPATIAL ANALYSIS}

Spatial analysis statistics were estimated through the use of the software FRAGSTATS (McGargial and Marks 1995). Statistics were calculated at both the landscape and class (Anderson-level category) spatial scales. The U.S. Department of Energy administrative boundary of the ORR set the analysis extent. The grain, the smallest spatial scale of resolution, was $25 \mathrm{~m} \times 25 \mathrm{~m}$ (i.e., the area of an individual Landsat TM pixel). 
Table 5. The amount of area of a particular land cover/land use which remained unchanged as determined by MATRIX analysis

\begin{tabular}{lc}
\hline \multicolumn{1}{c}{ Class } & $\begin{array}{c}\text { Area unchanged from 1984 to 1994 } \\
\text { (in ha) }\end{array}$ \\
\hline Water & 647.2 \\
Urban & 660.3 \\
Forest land & 7161.1 \\
Pasture land & 488.1 \\
Total & $\mathbf{8 9 5 6 . 7}$ \\
\hline
\end{tabular}

Table 6. The percentage of a land use/land cover in 1984 which changed and did not change (where classes coincide) in 1994 as determined by SUMMARY analysis

\begin{tabular}{lcccc}
\hline & $\begin{array}{c}\text { Water } \\
(\mathbf{1 9 8 4})\end{array}$ & $\begin{array}{c}\text { Urban } \\
(\mathbf{1 9 8 4})\end{array}$ & $\begin{array}{c}\text { Forest land } \\
\mathbf{( 1 9 8 4 )}\end{array}$ & $\begin{array}{c}\text { Pasture land } \\
(\mathbf{1 9 8 4})\end{array}$ \\
\hline $\begin{array}{l}\text { Water } \\
(1994)\end{array}$ & 65.7 & 1.1 & 2.1 & 1.9 \\
$\begin{array}{l}\text { Urban } \\
(1994)\end{array}$ & 4.5 & 66.4 & 3.4 & 15.6 \\
$\begin{array}{l}\text { Forest land } \\
(1994)\end{array}$ & 17.4 & 12.7 & 73.6 & 43.2 \\
$\begin{array}{l}\text { Pasture land } \\
(1994)\end{array}$ & 13.8 & 19.1 & 20.8 & 38.7 \\
$\begin{array}{l}\text { Barren land } \\
(1994)\end{array}$ & 0.2 & 0.6 & 0.2 & 0.7 \\
\hline
\end{tabular}

\subsubsection{Landscape}

Tables 7-9 record the results of the FRAGSTATS analysis program at the landscape spatial scale. Estimated statistics were shape-complexity (fractal dimension), patch, edge, diversity, and interspersion. The Double Log Fractal Dimension (DLFD), a measure of shape, was also calculated for each year $(1984=1.48$ and $1994=1.50)$. The number of patches increased $79 \%$ from 1984 to 1994 , and the mean patch size decreased $22 \%$ ( $44 \%$ unadjusted for standard deviation, Table 7 ). In a related manner, the amount of edge has increased 59\% from 1984 to 1994 with a corresponding increase in density (Table 8).

The Simpson diversity index ranges from 0 to 1 and measures the probability that two patches drawn at random from a landscape belong to the same class. High measures of diversity indicate that all classes within a landscape are fairly common The measure for both years is $\sim 0.60$ (Table 9). Simpson's evenness index ranges from 0 to 1 . Evenness measures the distribution of area among patch types. Large values imply greater landscape diversity (McGargial and Marks 1995). All class types are equally abundant at 1 and approach 0 when abundances diverge. The estimate for both years is $\sim 0.70$ (Table 9). 
Table 7. Landscape-level patch metrics

\begin{tabular}{cccc}
\hline Year & $\begin{array}{c}\text { Number of } \\
\text { patches }\end{array}$ & $\begin{array}{c}\text { Mean patch size } \\
\text { (ha) }\end{array}$ & $\begin{array}{c}\text { Patch size standard } \\
\text { deviation (ha) }\end{array}$ \\
\hline 1984 & 2901 & 11.13 & 376.49 \\
1994 & 5193 & 6.22 & 269.91 \\
\hline
\end{tabular}

Table 8. Landscape-level edge metrics

\begin{tabular}{ccc}
\hline Year & $\begin{array}{c}\text { Total edge } \\
(\mathbf{m})\end{array}$ & $\begin{array}{c}\text { Edge density } \\
(\mathbf{m} / \mathbf{h a})\end{array}$ \\
\hline 1984 & $1,370,475$ & 42.41 \\
1994 & $2,183,725$ & 67.57 \\
\hline
\end{tabular}

Table 9. Landscape-level diversity metrics

\begin{tabular}{cccc}
\hline Year & $\begin{array}{c}\text { Simpson } \\
\text { diversity index }\end{array}$ & $\begin{array}{c}\text { Simpson } \\
\text { eveness index }\end{array}$ & $\begin{array}{c}\text { Patch richness } \\
\text { (number of classes) }\end{array}$ \\
\hline 1984 & 0.58 & 0.73 & 4 \\
1994 & 0.60 & 0.70 & 5 \\
\hline
\end{tabular}

The interspersion and juxtaposition index (IJI) ranges from 0 to 100 and measures patch type adjacency. It measures the extent to which patches are interspersed. High values indicate high interspersion and low values indicate a disproportionate distribution of patch type adjacencies (McGargial and Marks 1995). Interspersion decreased 36\% from 1984 (66.39) to 1994 (42.29).

\subsubsection{Class}

Tables 10-12 record the results of the FRAGSTATS analysis program at the class spatial scale. Estimated statistics were patch, edge, fractal dimension, and interspersion. Table 10 shows the patch statistics at the class-level. Urban land has increased the number of patches by $42 \%$ at about the same size (Table 10). Forest land has increased the number of patches by $31 \%$, and they have decreased $41 \%$ in size. Pasture land has increased the number of patches by $98 \%$ at about the same size (Table 10 ). Accordingly for urban (21\%), pasture land (84\%), and forest land (66\%) edge has increased (Table 11$)$. Fractal dimension for all patch types (classes) was $\sim 1.5$ for all classes and did not change within a range of $0.02-0.04$. Table 12 records the results of IJ measure. The IJI measures for forest land has decreased by $56 \%$, decreasing patch adjacency to other patches. The IJI for pasture land has decreased by $31 \%$. 
Table 10. Class-level patch metrics (forest land and pasture land have become more fragmented)

\begin{tabular}{llccc}
\hline Year & Class & $\begin{array}{c}\text { Number of } \\
\text { patches }\end{array}$ & $\begin{array}{c}\text { Mean patch } \\
\text { size (ha) }\end{array}$ & $\begin{array}{c}\text { Patch standard } \\
\text { deviation }\end{array}$ \\
\hline 1984 & Water & 83 & 12.6 & 40.22 \\
1994 & Water & 84 & 11.08 & 57.42 \\
1984 & Urban & 759 & 1.46 & 15.99 \\
1994 & Urban & 1076 & 1.33 & 16.33 \\
1984 & Forest land & 386 & 25.84 & 469.33 \\
1994 & Forest land & 558 & 15.29 & 303.59 \\
1984 & Pasture land & 1671 & 1.23 & 8.26 \\
1994 & Pasture land & 3315 & 0.97 & 7.63 \\
1984 & Barren land & 0 & 0 & 0 \\
1994 & Barren land & 51 & 0.92 & 2.75 \\
\hline
\end{tabular}

Table 11. Class-level edge metrics

\begin{tabular}{llcc}
\hline Year & Class & $\begin{array}{c}\text { Total Edge } \\
(\mathbf{k m})\end{array}$ & $\begin{array}{c}\text { Edge density } \\
(\mathbf{m} / \mathbf{h} \mathbf{)})\end{array}$ \\
\hline 1984 & Water & 200 & 6.19 \\
1994 & Water & 191.9 & 5.94 \\
1984 & Urban & 406.4 & 12.58 \\
1994 & Urban & 491.5 & 15.21 \\
1984 & Forest land & 1008.7 & 31.21 \\
1994 & Forest land & 1676.9 & 51.89 \\
1984 & Pasture land & 999.5 & 30.93 \\
1994 & Pasture land & 1843.85 & 57.05 \\
\hline
\end{tabular}


Table 12. Class-level interspersion and juxtaposition metrics

\begin{tabular}{llc}
\hline Year & \multicolumn{1}{c}{ Class } & $\begin{array}{c}\text { Interspersion and } \\
\text { juxtaposition }\end{array}$ \\
\hline 1984 & Water & 73.39 \\
1994 & Water & 81.77 \\
1984 & Urban & 61.39 \\
1994 & Urban & 58.61 \\
1984 & Forest land & 67.96 \\
1994 & Forest land & 29.58 \\
1984 & Pasture land & 53.56 \\
1994 & Pasture land & 37.06 \\
1984 & Barren land & 0 \\
1994 & Barren land & 71.75 \\
\hline
\end{tabular}

\subsection{HABITAT MODELS}

High-quality nesting habitat on the ORR comprised $\sim 237.9$ ha, medium quality $\sim 92.3$ ha. There was no intersection for low-quality red-tailed hawk nesting habitat (Fig. 4). High quality feeding habitat comprised 2854 ha ( $20 \%$ of the ORR), medium $=206.2 \mathrm{ha} \mathrm{(} 1 \%$ of the ORR), and low quality occupies 11,110 hectares ( $78 \%$ of the ORR, Fig. 5).

For white-footed mouse, high-quality habitat comprised 2915.3 ha, medium $=8518$ ha, and low $=1798.2 \mathrm{ha}, 20.6 \%, 60.1 \%$, and $12.7 \%$, respectively, of the ORR landscape (Fig. 6). The rest of the ORR is comprised of water (i.e., rivers, streams, and ponds).

\section{CONCLUSIONS}

\subsection{DISCUSSION}

When compared with the surrounding area, the ORR landscape appears to be a contiguous block of mostly forest land (Mann et al. 1996). Alternatively, when compared to itself from 1984 to 1994, the change in patch size and number of patches at the landscape-level suggest fragmentation of the landscape. However, this assumption has two weaknesses. The first weakness is the need for contemporaneous independent ground truth data (e.g., aerial photography) to validate the changes between 1984 and 1994. The individual accuracy assessment values provide some insight into the error but do not provide a measure of accuracy at specific locations. The second weakness is the seasonality of the data. A full forest canopy in the fall of 1984 is compared with a beginning canopy in the early spring of 1994. In 1994, the understory is more fully exposed because of the lack of leaf cover and this would tend to give a fragmented appearance to the forest. 


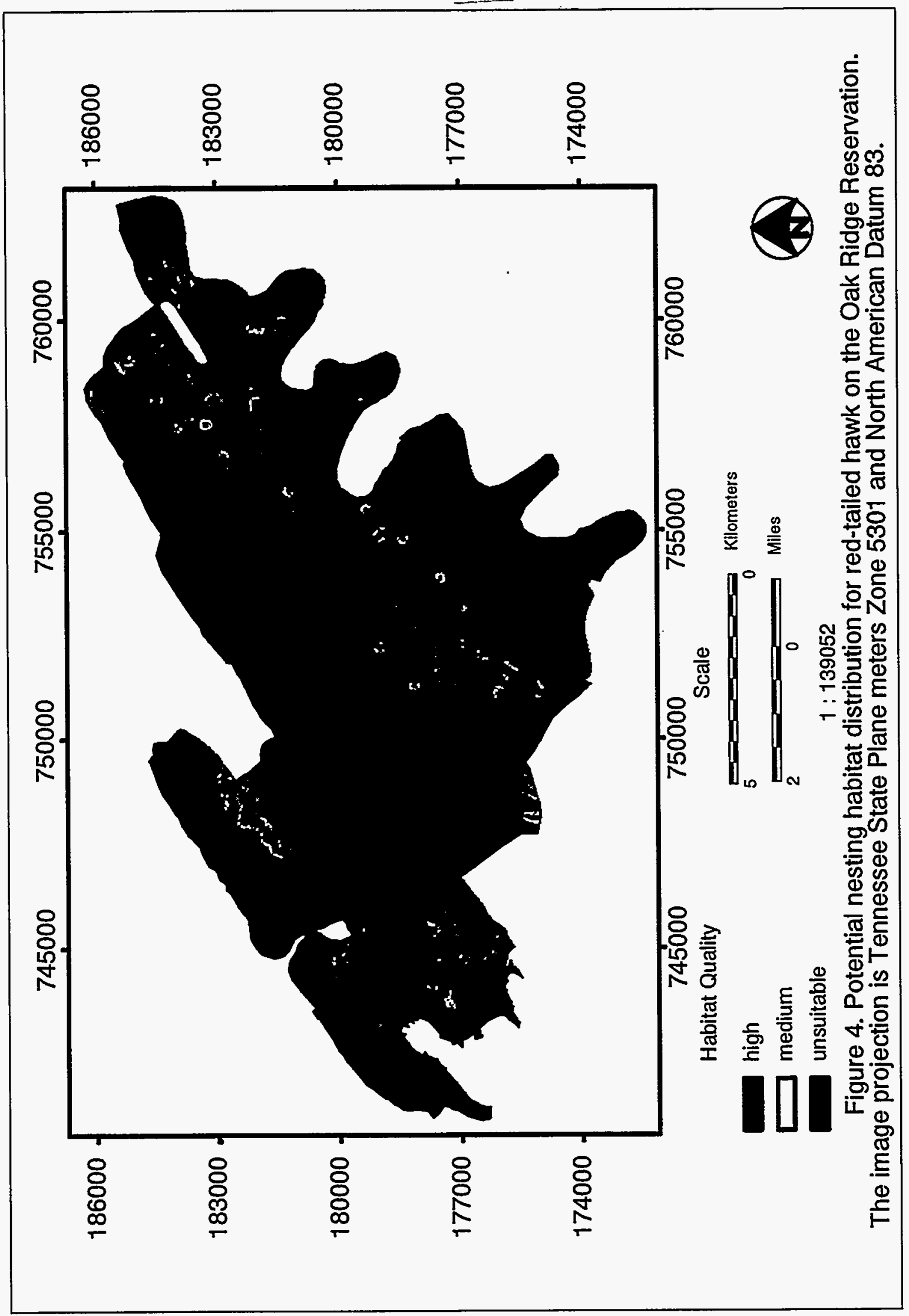




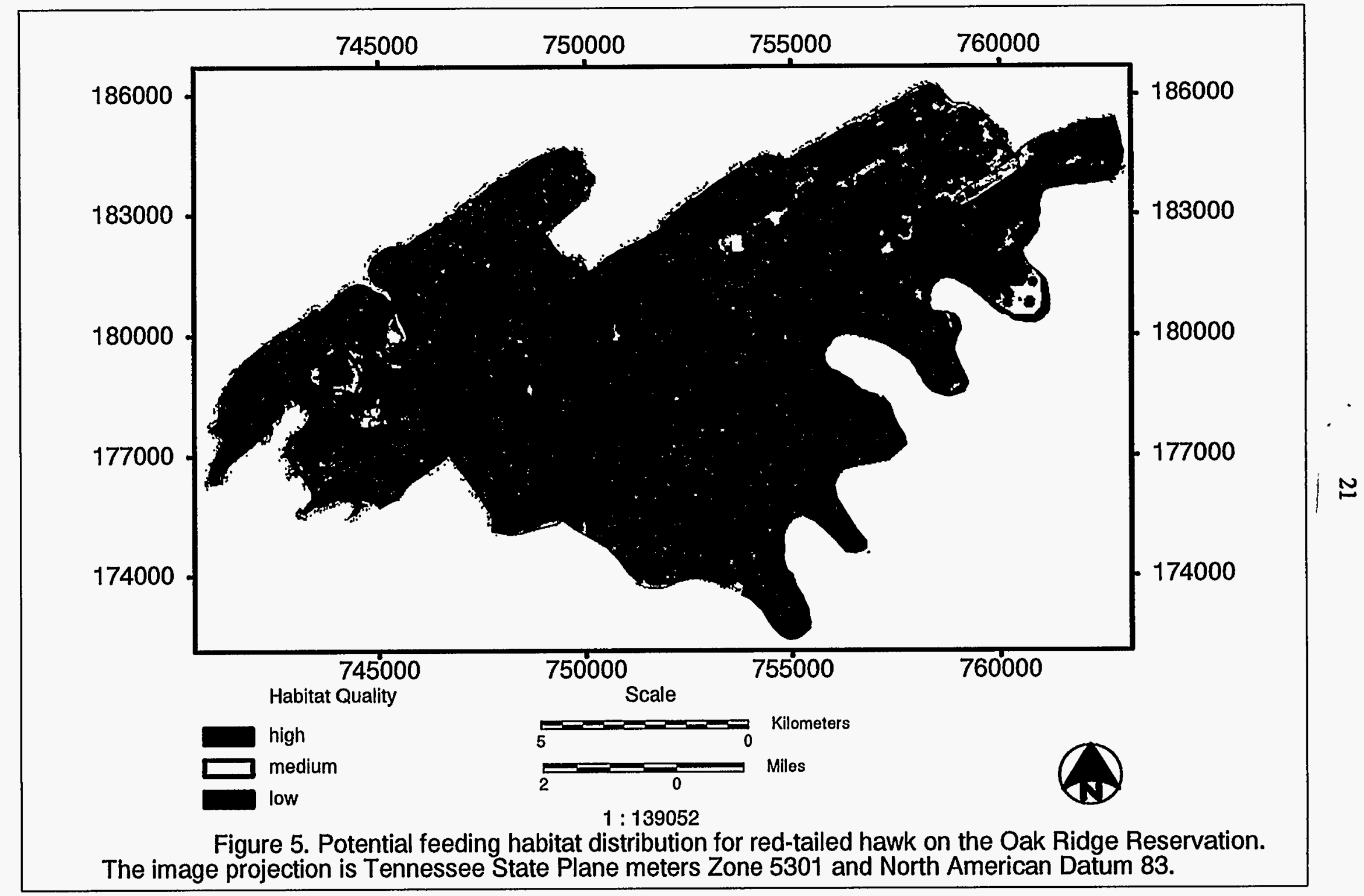




d




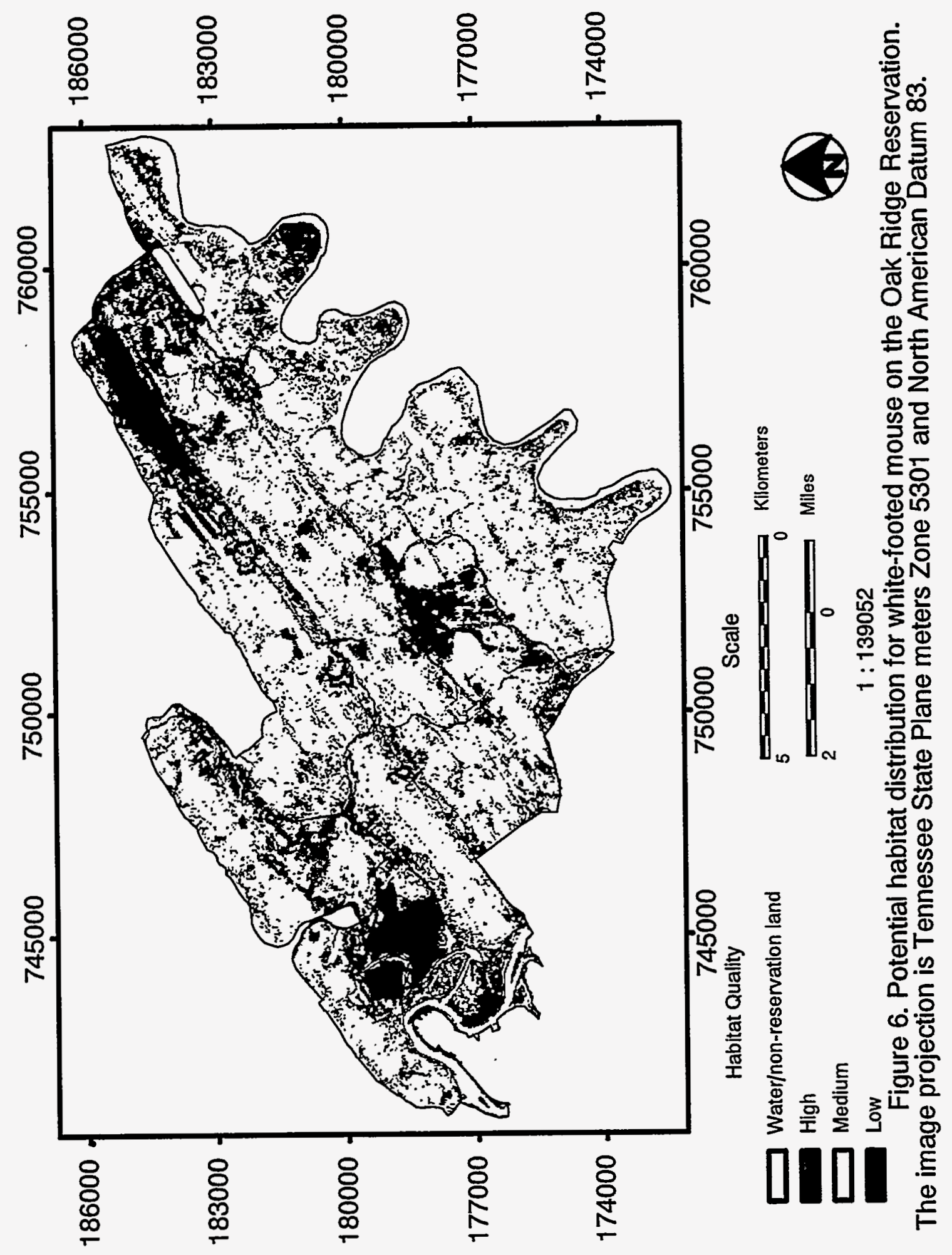


Also, a number of the gaps/patches that led to forest fragmentation are too large to be filled when a full canopy becomes present. Many of these gaps are consistent with pine-beetle infestations on the ORR. Although not ground truthed, this fragmentation appears to have happened especially between the forest land and pasture land cover classes. In addition to fragmentation, data analysis indicates a $10 \%$ net loss of the forest land cover type. Forest land composed some 70\% of the landscape in 1984 and this has been reduced to $60 \%$, perhaps largely because of pine-beetle death and subsequent harvest of dead pines. Approximately $21 \%$ of forest land in 1984 had been converted to pasture land with urbanization (conversion to urban land) capturing $3 \%$. There has not been a large change in shape-complexity as measured by the fractal dimension, but the size of forest land patches has decreased and the edge has increased. It should be noted again that there is some confusion between the Anderson level II: pasture land and forest land categories, because transitional areas, areas where secondary plant succession is actively occurring, was aggregated with pasture land. Transitional areas include forest sites that were pine-beetle killed and harvested. It has been estimated that $\sim 1100$ ha of evergreen forest has been recently harvested, a figure comparable to the forest land to pasture land category in Table 4 (1236.81 ha, Linda Mann for Pat Parr, 1996, personal communication). Transitional areas tended to have confusion between spectral signatures with forest land categories (Washington-Allen et al. 1995). Therefore, the degree of loss, increased fragmentation, and edge of forest should be viewed as an overestimate. Regardless, the landscape structure hypothesis predicts that smaller patches lead to a decline in interior species, and increased edges lead to an increase in edge species (McGarigal and $\mathrm{McComb} 1995$ ). With an alteration in forest habitat this has been observed for red-tailed hawk, where with an increase in edge they increase in abundance (Morman and Chapman 1996).

Pasture land had a net increase of $9 \%$. Pasture land lost $43 \%$ to forest land but gained from urban and water (Table 6). A gain from the water is probably a reflection of floodplain changes; however, gaining from urban is probably a function of confusion between the classifications of the two categories where the urban category includes cut-lawn (Washington-Allen et al. 1995); thus, for both pasture land and forest land, the conversion to urban $(3 \%)$ is probably an underestimate. Spatial analysis indicates that pasture land had a $98 \%$ increase in patches, which were of comparable size to the size in 1984 , thus becoming a more fragmented class. As expected, edge increased accordingly.

The fractal dimension, DLFD, has a range from 1 to 2, with DLFD approaching 2 indicative of increasing shape complexity. Krummel et al.(1987) discovered that the fractal dimension could be used to measure anthropogenic impact on a landscape where land management in the western hemisphere tended to homogenize landscapes to simple geometric shapes (e.g., urban and agricultural patterns tend to be planar); thus, D approached 1. At a 0.02 difference (an increase in 1994), there does not appear to be a significant change in shape between the landscape in 1984 and 1994. There does not appear to be a significant change in shape for individual classes.

The models of spatial habitat relationships for red-tailed hawk and white-footed mouse should be viewed as an overestimate. Potential habitat is delineated, but improvements to the GIS-modeling would be required to approach actual habitat distribution. For example, general categories of evergreen forest and evergreen plantation were used, but previous studies had indicated that the GIS-models for both raptors and mice could be improved if the age of theses forest types had also been included. Further improvements would include natural and anthropogenic disturbances that lead to habitat alteration, removal, and, thus, fragmentation; and biological factors such as prey-predator relationships that lead to behavioral changes and demographic adjustments. The white-footed mouse spatial habitat-relationship model is a surrogate model of feeding habitat for gray fox [i.e., the mouse is a major component of gray fox diet on the ORR (Greenberg, Pelton, and Parr 1988)]. This model is therefore an example of modeling biological factors such as prey-predator relationships. 


\subsection{RECOMMENDATIONS}

Exponential, linear, or other polynomial models can be used to predict the rate of change of LULC on the ORR from the comparison of our two images. Hett (1971) used the difference in amount of land occupied by a category from one time period to the next divided by the number of years between measurements in comparing the rate of change in East Tennessee (e.g., for the ORR forest land the rate of change would be $1.41 \mathrm{~km}^{2} /$ year). Because it is an overestimate, this is probably comparable to the mean rate of change for forest land between 1939 and 1964 for 3 counties in East Tennessee $\left(0.80 \mathrm{~km}^{2} /\right.$ year $)$ and for Roane county, which contains the ORR (0.79 km²/year, Hett 1971). Hett (1971) used the rates of change as coefficients in a simulation model to predict rates of change at county and regional scale for East Tennessee. However, a number of endemic climatically driven natural disturbances occur on the ORR (e.g., pine-beetle, tornadoes, heavy winter snow, and high winds), which can drastically alter the landscape and are not amenable (as yet) to spatial and temporal prediction because of their chaotic behavior (Gleick 1987). Secondly, from a statistical perspective, two points in time are not adequate for time-series analysis (i.e., discernment of temporal pattern) especially when attempted independent of site-management data. Given this unpredictability, we would recommend image acquisition on a yearly, same-date time-step (anniversary). A longer term data set of at least 5 years of anniversary images, with adequate reference sites for validation of findings, coupled with site-management data of the activities of humans and other biota would provide an adequate foundation for environmental monitoring.

The results of the three analyses provide a basis for future investigations of how LULC changes, particularly the widespread dispersal of radioactive and nonradioactive contaminants will affect the biodiversity of the ORR A preliminary measure of potential risk would be the intersection of GIS-based maps of waste-area sites that contain these contaminants (on the ORR these sites are called operable units (OUs) and waste area groupings (WAGs)] with individual species' GIS-based habitat distribution or species richness maps. Where studies are numerous and in depth on the natural history of individual target species, GIS-based models of their potential distribution can be developed. However, a further step would be to carry out field surveys of the actual distribution of individual species' habitat to provide an "accuracy assessment" or comparison of potential distribution of the GIS-based spatial models to actual distribution (e.g., Dale et al. 1996).

Spatial analysis was applied to the ORR at the landscape and class scale of LULC. The same analyses should be applied to individual species habitat or representations of functional groups or guilds (e.g., area-sensitive species or body-size class). The spatial pattern of habitats within landscapes may influence abundance, distribution, and dynamics of vertebrate populations (Wiens 1976). Fragmentation and the alteration of habitat geometry subdivides populations and may create a metapopulation structure that will affect the persistence of a species or functional group (Gilipin and Hanski 1991; Holling 1992). This study indicates that fragmentation and alteration of the geometry of vegetation cover classes has occurred, but lack of ground truth of LULC category changes and the mismatch in seasonality of the data leave the magnitude of fragmentation and other landscape measures unknown.

Point data of soil concentration-levels are available from the Oak Ridge Environmental Information System and literature values of the physics of radiation propagation for individual contaminants are available which could be used for landscape-level ecological risk assessment. Sample and Suter (1994) developed individual spatially aggregated (a nongeographic locational magnitude or probability value of an effect, Turner and Dale 1991) oral-exposure models for terrestrial wildlife on the ORR that are amenable to GIS-modeling. Ecological risk of radioactive and nonradioactive contaminants could be determined by relating point or spatially interpolated point data to species' habitat-relationship models

within a GIS. The result would be a spatially explicit model of the ecological risk of exposure, which 
would indicate the geographic location(s) or address of the risk of exposure at different magnitudes and spatial probabilities. Individual layers of each species' magnitude of exposure could then be overlain to get an estimate of "species exposure richness" and other measures of biodiversity on the ORR. 


\section{REFERENCES}

Anderson, J. R, et al. 1976. "A Land Use and Land Cover Classification System for Use with Remote Sensor Data," U. S. Geological Survey Professional Paper 964, p. 28.

Ashwood, T. L., et al. 1994. Work Plan for the Oak Ridge Reservation Ecological Monitoring and Assessment Program, DOE/OR/01-1298\&D1 (ES/ER/TM-127\&D1), Martin Marietta Energy Systems, Inc., Oak Ridge, Tenn.

Askins, R. A., F. M. Ewert, and R. I. Norton. 1989. "Abundance of Wintering Migrants in Fragmented and Continuous Forests in the U.S. Virgin Islands," pp. 197-206. In The Proceedings of Manomet Symposium.

Bierregaard, R. O., et al. 1992. "The Biological Dynamics of Tropical Rainforest Fragments," Bioscience 42:859-66.

Braun, E. L. 1950. Deciduous forests of eastern North America. Blakiston, Philadelphia.

Burrough, P. A. 1986. Principles of Geographical Information Systems for Landscape Resources Assessment, Oxford University Press, New York, p. 194.

Cairns, J., Jr. and B. R. Niederlehner. 1996. "Developing Field of Landscape Ecotoxicology," Ecological Applications, 6:790-6.

Campbell, J. B. 1987. Introduction to Remote Sensing, Guilford Press, New York, p. 551.

Congalton, R. 1991. "A Review of Assessing the Accuracy of Classifications of Remotely Sensed Data," Remote Sensing of Environment, 37:35-46.

Dale, V. H., et al. (submitted) 1996. "Assessing Land-Use Impacts on Natural Resources," Environmental Management.

ERDAS. 1994. ERDAS Field Guide, Erdas, Inc, Atlanta, p. 628.

Forman, R. T. T., and M. Godron. 1986. Landscape Ecology, John Wiley \& Sons, New York.

Gilpin, M. E. and I. Hanski, eds. 1991. Metapopulation Dynamics: Empirical and Theoretical Investigations, Academic Press, San Diego.

Gleick, J. 1987. Chaos: Making A New Science, Viking, New York, p. 352.

Greenberg, C. H., M. R. Pelton, and P. D. Parr. 1988. Gray Fox Ecology in the Oak Ridge National Environmental Research Park: Food Habits, Home Range, and Habitat Use, ORNL/NERP-3, Oak Ridge Natl. Lab., Oak Ridge, Tenn., p. 160.

Greller, A. 1988. "Deciduous Forest," pp. 288-316 in North American Terrestrial Vegetation (M. G. Barbour and W. D. Billings, eds.). Cambridge University Press, New York, p. 434. 
Hatcher, R. D., et al. 1992. Status Report on the Geology of the Oak Ridge Reservation, ORNL/TM12074, Oak Ridge National Laboratory, Oak Ridge, Tenn.

Hett, J. M. 1971. Land Use Change in East Tennessee and a Simulation Model Which Describes These Changes for Three Counties, ORNL-IBP-71-8, International Biological Program UC-48 Biology and Medicine, Ecological Sciences Division, Contract No. W-7405-eng-26, p. 56.

Holling, C. S. 1992. “Cross-Scale Morphology, Geometry, and Dynamics of Ecosystems,” Ecological Monographs, 62(4)447-502.

Hopkins, L. D. 1977. "Methods for Generating Land Suitability Maps: a Comparative Evaluation," Journal of American Planners, 43:386-400.

Jensen, J. R., 1996. Introductory Digital Image Processing: A Remote Sensing Perspective, Prentice Hall, New Jersey, p. 379.

King, A. L., D. J. Awl, and C. A. Gabrielson. 1994. Environmentally Sensitive Areas Surveys Program Threatened and Endangered Species Survey: Progress Report, ES/ER/TM-130, Health Sciences Research Division, Oak Ridge Natl. Lab., Oak Ridge, Tenn.

Krummel, J. R, et al. 1987. "Landscape Configurations in a Disturbed Environment," Oikos, 48:321-4.

Levine, D., Oak Ridge National Laboratory, Computational Physics and Engineering Division. July 22, 1996. Re: Floodplain Coverage. Electronic mail to R. A. Washington-Allen, Oak Ridge National Laboratory, Environmental Sciences Divison, Oak Ridge, Tenn.

Mann, L. K., et al. 1996. "Protection of Biota on Nonpark Public Lands: Examples from the U.S. Department of Energy Oak Ridge Reservation," Environmental Management, 20(2):207-18.

McGarigal, K and B. J. Marks. 1995. FRAGSTATS: Spatial Pattern Analysis Program for Quantifying Landscape Structure, U.S. Forest Service General Technical Report PNW 351.

McGarigal, K. and W. McComb. 1995. "Relationship Between Landscape Structure and Breeding Birds in the Oregon Coast Range," Ecological Monographs, 63(5):235-60.

Morman, C. E., and B. R. Chapman. 1996. "Nest-Site Selection of Red-Shouldered and Red-Tailed Hawks in a Managed Forest," Wilson Bull.,108(2):357-68.

Murdock, N. A. 1994. "Rare and Endangered Plants and Animals of the Southern Appalachian Wetlands Water," Air and Soil Pollution, 77:385-405.

Nelson, B.B. and K. Titus. 1988. "Siliviculture Practices and Raptor Habitat Associations in the Northeast." pp 171-179 in Proceedings of the Northeast Raptor Management Symposium and Workshop (B.G. Pendelton, M. N. Lefranc, Jr., M. B. Moss, C. E. Ruibal, M. A. Knighton, D. L. Krahe, eds.). National Wildlife Federation of Science and Technology Service No. 13.

Noss, R F. 1983. “A Regional Landscape Approach to Maintain Diversity," Bioscience, 33(11):700-6.

O’Neill, R. V., et al. 1988. “Indices of Landscape Pattern," Landscape Ecology, 1:153-62. 
Parr, P. D., and J. W. Evans. 1992. Resources Management Plan for the Oak Ridge Reservation, Vol. 27: Wildlife Management Plan, ORNL/NERP-6, Oak Ridge, Tenn.

Ritter, K. H., et al. 1995. “A Factor Analysis of Landscape Pattern and Structure Metrics," Landscape Ecology, 10:23-39.

Sample, B. E., L. A. Baron, and B. L. Jackson. 1995. Preliminary Assessment of the Ecological Risks to Wide-Ranging Wildlife Species on the Oak Ridge Reservation, DOE/OR/01-1407\&D1, Environmental Sciences Division Publication No. 4449, Martin Marietta Energy Systems, Inc., Oak Ridge, Tenn.

Sample, B. E. and G. W. Suter, II. 1994. Estimating Exposure of Terrestrial Wildlife to Contaminants, ES/ER/TM-125, Environmental Sciences Division, Martin Marietta Energy Systems, Inc., Oak Ridge, Tenn.

Scott, J. M., et al. 1993. "Gap Analysis: A Geographic Approach to Protection of Biological Diversity," Wildlife Monographs, 123:1-41.

Smyre, J. 1994. "Derived from United States Geological Survey 7.5 Minute Quadrangles," Computational Physics and Engineering Division, Oak Ridge Natl. Lab., Oak Ridge, Tenn.

Stoms, D. M. and J. E. Estes. 1993. “A Remote Sensing Research Agenda for Mapping and Monitoring Biodiversity," International Journal of Remote Sensing, 14(10):1839-60.

Sutton, A. and M. Sutton. 1985. Eastern Forests, Alfred A. Knopf, New York, p. 638.

Tennessee Valley Authority. 1988. "Electronically Extracted from Oak Ridge S-16a Area Map Data," Tennessee Valley Authority, Knoxville, Tenn.

Tennessee Valley Authority. 1991. "Flood Analyses for DOE Y-12, K-25, and ORNL Plants," Flood Protection Section, Water Resources Operations Department, Water Resources Division, Tennessee Valley Authority, Knoxville, Tenn., December.

Titus, K., and J. A. Mosher. 1981. "Nest-Site Habitat Selected by Woodland Hawks in the Central Appalachians," Auk 98:270-81.

Turner, M. G. 1989. "Landscape Ecology: The Effect of Pattern on Process," Annual Review of Ecology and Systematics, 20:171-97.

Turner, M. G. and R. Gardner (eds.). 1991. Quantitative Methods in Landscape Ecology. Vol. 82, Springer-Verlag, New York, p. 536.

Turner, M. G. and V. H. Dale. 1991. "Modeling Landscape Disturbance," pp. 323-51 in Turner, M. G. and R. Gardner (eds.), Quantitative Methods in Landscape Ecology, Vol. 82, Springer-Verlag, New York, p. 536.

Washington-Allen, R. A., et al. 1995. Terrestrial Habitat Mapping of the Oak Ridge Reservation: Phase 1, ES/ER/TM-152 (Environmental Sciences Division Publication No. 4394), Martin Marietta Energy Systems, Inc., Oak Ridge, Tenn. 
Westman, W. 1985. Ecology, Impact Assessment, and Environmental Planning, John Wiley \& Sons, New York, p. 532.

Wiens, J. A. 1976. "Population Response to Patch Environments," Annual Review of Ecology and Systematics, 7:81-129. 


\section{DISTRIBUTION}

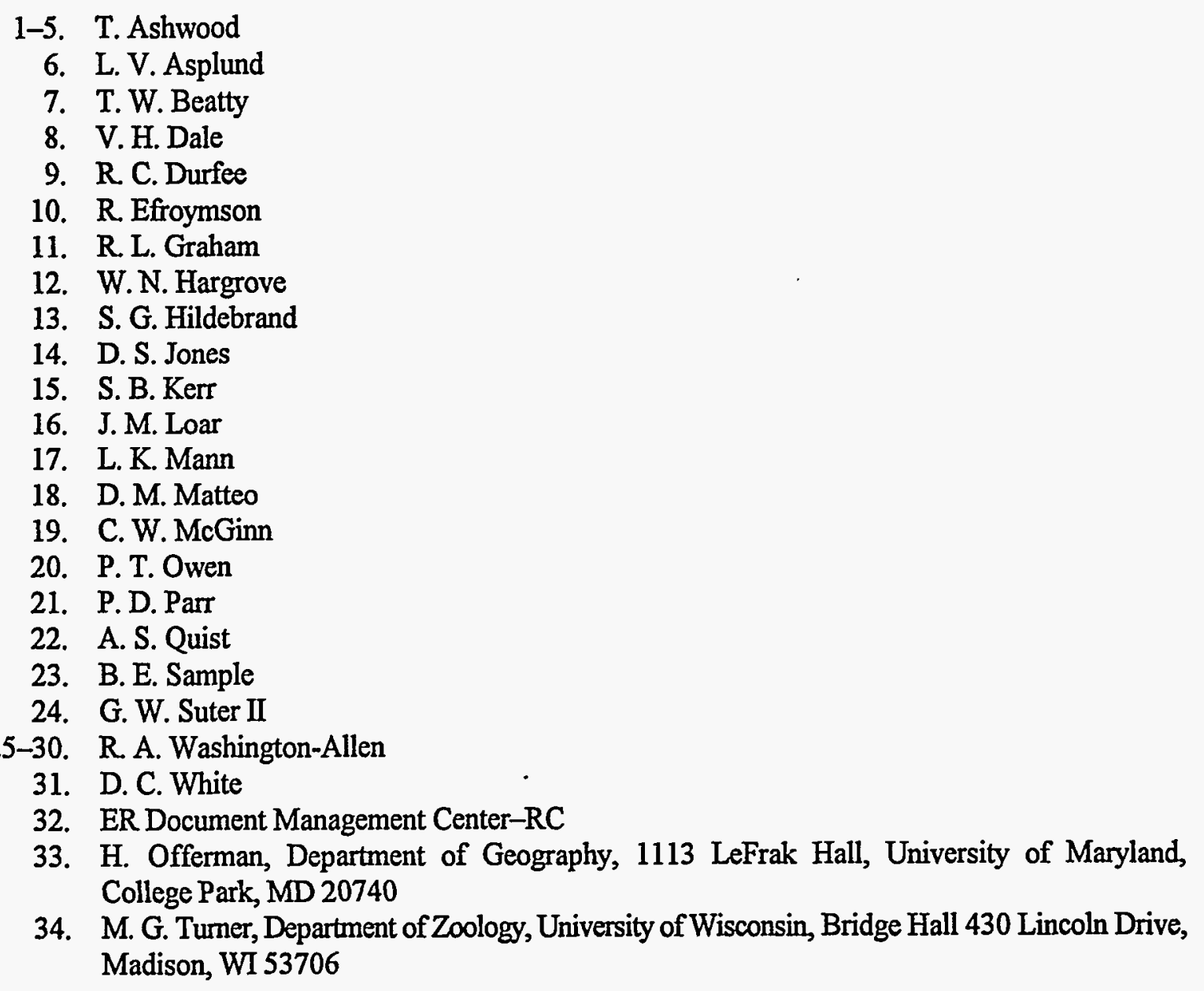

